\title{
Identification of Membrane Proteins That Comprise the Plasmalemmal Junction between Migrating Neurons and Radial Glial Cells
}

\author{
Richard S. Cameron ${ }^{\mathrm{a}}$ and Pasko Rakic \\ Section of Neurobiology, Yale University School of Medicine, New Haven, Connecticut 06510-8001
}

\begin{abstract}
We have initiated studies to identify membrane polypeptides of radial glial cells that contribute to the selective cell-cell recognition and migration events in developing brain. Of several polyclonal antisera evaluated, one (D4), developed against formaldehyde fixed type 1 cerebellar glial cells, immunolabels the free surface of cortical and cerebellar astroglial and radial glial cells in a patchy pattern. In dissociated glial-neuronal cell cocultures, microdomains of immunoreactivity are detected at the site where the somal region of cells with the morphology of migrating neurons is in contact with an elongated glial cell fiber. Microdomains are absent from oligodendrocytes, process-bearing astrocytes, and neurons. The surface microdomains do not colocalize with components that compose focal adhesion plaques -integrin subunits, vinculin, or actin-and their integrity appears to require an intact microtubule rather than actin cytoskeleton. Furthermore, microdomain structure is maintained in the absence of extracellular $\mathrm{Ca}$ and $\mathrm{Mg}$ ions. Immunoblot analyses using antibodies affinity purified to individual proteins indicate that the microdomains are composed of two antigens with apparent molecular mass of $\sim 48$ $\mathrm{kDa}$ and $\sim 72 \mathrm{kDa}$. The $48 \mathrm{kDa}$ antigen is not observed in non-neural epithelial tissues and is detected in cortical and cerebellar tissues only at a developmental period that coincides with the stage of active neuronal cell migration. In contrast, the $72 \mathrm{kDa}$ antigen is expressed in many neural and non-neural tissues at late developmental and adult stages. Our data suggest that the identified membrane proteins may contribute to the formation of the junction between migrating neurons and radial glial cell processes and that this junctional complex is linked to the microtubule cytoskeleton.
\end{abstract}

IKey words: neuronal cell migration, corticogenesis, cellcell junction, adhesion proteins, membrane proteins, cytoskeleton]

\footnotetext{
Received Apr. 15, 1993; revised Oct. 21, 1993; accepted Nov. 1, 1993.

This research was supported by Public Health Service grants from the National Institutes of Health (NS14841, NS22807). We gratefully acknowledge Drs. P. L. Cameron and $\mathrm{H}$. Komuro for discussions during the course of this work and Drs P. L. Cameron, S. Hockfield, and R. Levenson for valuable comments on the manuscript. We also thank Dr. P. DeCamilli for use of the fluorescent microscope and members of the Department of Cell Biology for use of electrophoresis and centrifugation equipment.

Correspondence should be addressed to P. Rakic, Section of Neurobiology, Yale University School of Medicine, 333 Cedar Street, New Haven, CT 06510-8001.

Present address: Institute of Molecular Medicine and Genetics, Department of Medicine, Medical College of Georgia, Augusta, GA 30912-3175.

Copyright (C) 1994 Society for Neuroscience $0270-6474 / 94 / 143139-17 \$ 05.00 / 0$
}

The majority of ncurons in the developing CNS are generated in proliferative zones that are located at a distance from their resident positions in the adult brain (Sidman and Rakic, 1973; Rakic, 1985, 1990). Observations over the past two decades have provided detailed evidence that the intervening process of neuronal cell migration may take place along a cellular substrate provided by elongated radial glial cells (Rakic, 1971, 1972; Hatten and Mason, 1990; Misson et al., 1991). This mode of neuronal cell migration is particularly prominent during the formation of laminar structures such as the neocortex and hippocampus, but also, to a lesser degree, in the developing diencephalon, mesencephalon, brainstem, and spinal cord (Rakic, 1977, 1990; Nowakowski and Rakic, 1979; Eckenhoff and Rakic, 1984; Schults et al., 1990).

While the phenomenon of neuronal cell migration has been known for more than a century (Ramon y Cajal, 1891), identification of the molecular components underlying selective ncuronal cell displacement to specific laminae and nuclear aggregates is only beginning to emerge. At present, considerable evidence indicates that many of the cell-cell recognition/adhesive interactions that participate in neural cell sorting and migration are mediated by members of several distinct classes of cell adhesion receptors. Principal among these are members of the immunoglobulin superfamily (Friedlander et al., 1989; Edelman and Crossin, 1991), the integrin family (Galileo et al., 1992; Hynes, 1992), the cadherin family (Nose et al., 1988; Takeichi, 1991; Shimamura and Takeichi, 1992), and components of the extracellular matrix (Sheppard et al., 1991). Recently, atypical adhesion receptors have been identified including a subset of receptor-like tyrosine protein phosphatases (BradyKalnay et al., 1993; Gebbinks et al., 1993) and several cell surface enzymes (Gloor et al., 1990; Rao and Hausman, 1993). However, with few exceptions (Antonicek et al., 1987; Fishell and Hatten, 1991; Vogel et al., 1992), analyses of these adhesion polypeptides have indicated a diversity of roles in neuronalneuronal and neuronal-glial cell interactions. Thus, the membrane components specific to radial glial cells that may be engaged in selective cell recognition, adhesion, or translocation events during neuronal migration remain to be identified.

The development of in vitro neuronal cell migration assay systems has begun to allow detailed analyses of the selective cellular and molecular mechanisms that underlie neuronal cell migration. Hatten and colleagues (Hatten and Mason, 1990) have reconstituted neuronal cell migration along elongated astroglial cell processes in vitro, and several groups have analyzed neuronal cell migration in slice cultures (Komuro and Rakic, 1992; Roberts et al., 1993). The ultrastructural characteristics of migrating neurons and the dynamics of their movement ob- 
served in in vitro cell preparations (Edmondson and Hatten, 1987; Gregory et al., 1988; Fishell and Hatten, 1991; Komuro and Rakic, 1992; Roberts et al., 1993) resemble those derived from in vivo analyses (Rakic, 1971, 1972). Notably, assembly of a junctional complex between the migrating neuronal cell soma and the radial glial cell process appears to be a critical event in initiating and maintaining neuronal cell migration (Rakic, 1972, 1990; Gregory et al., 1988; Fishell and Hatten, 1991). Disruption of this junctional complex leads to a cessation in neuronal cell migration (Fishell and Hatten, 1991). At present, however, neither the membrane nor the cytoskeletal components that comprise this specialized interstitial or "migration" junction have been elucidated.

The present study was designed for the identification and isolation of glial cell plasma membrane proteins that may participate in selective cell migration events in developing brain. Toward this goal, multiple polyclonal antisera were developed against isolated plasma membrane fractions obtained from type 1 and stellate cerebral cortical and cerebellar astrocytes as well as formaldehyde-fixed isolated type 1 and stellate cortical and cerebellar astrocytes. Use of this strategy has led to the identification and characterization of two novel membrane polypeptides that appear to contribute to the interstitial junction between migrating neurons and radial glial cells.

\section{Materials and Methods}

Materials. Rhodamine-conjugated goat anti-rabbit IgGs (heavy and light chain specific) were obtained from Cappel Organon Teknika (Durham, NC); FITC-conjugated goat anti-mouse IgGs, from Sigma Chemical Co. (St. Louis, MO); and ABC Vectastain kits, from Vector Laboratories (Burlingame, CA). Tissue culture media and sera were purchased from GIBCO/Bethesda Rescarch Laboratorics (Gaithcrsburg, MD) and HL1 supplement from Ventrax (Portland, ME). Carrier ampholines were from LKB Instruments (Gaithersburg, MD); molecular mass standards and other electrophoresis reagents were from Bio-Rad Laboratories (Richmond, CA). Percoll was purchased from Pharmacia (Piscataway, NJ). Polyclonal antiserum raised against glial fbrillary acidic protein (GFAP) was supplied by Dakopatts (Santa Barbara, CA), and against $\alpha 1$-integrin from Chemicon (Temecula, CA). Monoclonal antibodies developed against vimentin, $\beta$-tubulin, and vinculin were obtained from Miles Scientific (Naperville, IL), Amersham (Arlington Heights, IL), and Boehringer Mannheim (Indianapolis, IN), respectively. Rhodamine-phalloidin was obtained from Molecular Probes, Inc. (Eugene, $O R$ ); enhanced chemiluminescence (ECL) kit, from Amersham Corp. (Arlington Heights, IL). N-glycosidase F recombinant was purchased from Bochringer Mannhcim (Indianapolis, IN), and trifluoromethancsulfonic acid (TFMS) from Aldrich Chemical (Milwaukee, WI). All other supplies were from general distributors.

Cells. Primary mixed glial cell cultures were prepared from cerebral cortices and cerebella obtained from neonatal rats (timed-pregnant Sprague-Dawley rats, Charles River Breeding Laboratories, Inc., Wilmington, MA) according to the procedures described by Levison and McCarthy (1991). Isolated cerebral cortices and cerebella, freed of associated meninges, were minced with a razor blade and a single-cell suspension was prepared by trypsin digestion [in Dulbecco's modified Eagle medium (DMEM) supplemented with $1 \mathrm{mg} / \mathrm{ml}$ trypsin, $20 \mu \mathrm{g} / \mathrm{ml}$ DNase, $30 \mathrm{~min}$ at $370^{\circ} \mathrm{C}, 95: 5 \% \mathrm{O}_{2}: \mathrm{CO}_{2}$ ] and subsequent trituration using descending bore fire-polished Pasteur pipettes. Cultures were maintained at $37^{\circ} \mathrm{C}$ in a humidified atmosphere of $5 \% \mathrm{CO}_{2}$. After $8-10$ $\mathrm{d}$ in culture, $\mathrm{O}-2 \mathrm{~A}$ progenitor cells and oligodendroglia growing on top of the astrocyte monolayer were obtained according to Levison and McCarthy (1991). Isolated cells were cultured subsequently in serumfree medium (DMEM supplemented with $2 \mathrm{~mm}$ glutamine and $1 \% \mathrm{HLl}$ ) for generation of oligodendrocytes (Raff, 1989).

PC1 2 cells (Greene and Tischler, 1976), grown without nerve growth factor, were provided by Drs. P. L. Cameron and P. DeCamilli (Yale University) and grown as described (Cameron et al., 1991). The rat glioma cell line C6, obtained from American Type Culture Collection (Rockville, MD), was provided by Dr. D. Barber (Yale University) and grown in DMEM supplemented with 5\% fetal calf serum and 10\% horse serum.

Cerebellar granule neurons were prepared from 5 and $12 \mathrm{~d}$ postnatal cerebelli by cell fractionation using discontinuous Percoll gradients (Hatten, 1985). Briefly, a single-cell suspension was prepared by trypsin digestion (DMEM supplemented with $1 \mathrm{mg} / \mathrm{ml}$ trypsin, $20 \mu \mathrm{g} / \mathrm{ml}$ DNase, $30 \mathrm{~min}$ at $37^{\circ} \mathrm{C}, 95: 5 \% \mathrm{O}_{2}: \mathrm{CO}_{2}$ ) and subsequent trituration using dcscending bore fire-polished Pasteur pipettes. Cells, sedimented by centrifugation $\left(15 \mathrm{~min}\right.$ at $100 \mathrm{~g}, 18^{\circ} \mathrm{C}$, Beckman GPR centrifuge, GH 3.7 rotor), were resuspended in $\mathrm{Ca}^{2+} / \mathrm{Mg}^{2+}$-free Hanks' balanced salt solution supplemented with $10 \mathrm{~mm}$ HEPES (pH 7.4), $1 \mathrm{~mm}$ EDTA, and $5 \%$ Percoll and filtered through $47 \mu \mathrm{m}$ nylon mesh. The filtrate $(2 \mathrm{ml})$ was layered over a Percoll step gradient having underlayers of $3 \mathrm{ml}$, $35 \%$, and $3 \mathrm{ml}, 60 \%$ Percoll (containing the supplements specified previously). Centrifugation ( $30 \mathrm{~min}$ at $650 \mathrm{~g}$ in a Beckman $\mathrm{GH} 3.7$ rotor) yielded a purified granule cell fraction at the $35 \% / 60 \%$ Percoll interface. Following sedimentation in DMEM $(1: 5 \mathrm{v} / \mathrm{v})$, purified granule cells were resuspended in DMEM supplemented with 2 mM glutamine, $1 \% \mathrm{HL}$, and $10 \%$ fetal calf serum.

Primary hippocampal neuronal cell cultures were prepared from the hippocampi of $18 \mathrm{~d}$ embryonic rats according to Banker and Cowan (1977) and Bartlett and Banker (1984) as described by Cameron et al. (1991).

In both cases, dissociated cells were plated on poly-L-lysine-treated glass coverslips at $3 \times 10^{4} \mathrm{cell} / \mathrm{cm}^{2}$, for immunocytochemical analyses, or poly-L-lysine-treated petri dishes at $4 \times 10^{5} \mathrm{cells} / \mathrm{cm}^{2}$, for biochemical analyses.

Preparation and immunochemical characterization of antiserum. New Zealand White rabbits (female, 2-2.5 kg; Pineacres, West Brattleboro, VT) were bled 1 week prior to immunization in order to obtain preimmune serum. For the development of the polyclonal antiserum (D4), adhered cerebellar astroglial cells, 6-8 d in vitro (prepared from singlecell dissociates of cerebelli obtained from $<24 \mathrm{hr}$ rats as described under Cells, above) were removed by trypsinization/EDTA treatment. Trypsinized cells, collected by centrifugation $(15 \mathrm{~min} \times 200 \mathrm{~g})$ and further cultured in suspension $(6-8 \mathrm{hr})$, were subsequently fixed by suspension in $3 \%$ formaldehyde containing $250 \mathrm{~mm}$ sucrose, $120 \mathrm{~mm}$ sodium phosphate ( $\mathrm{pH}$ 7.4) for 60 min at $4^{\circ} \mathrm{C}$. Cells were washed ( 250 mm sucrose, $120 \mathrm{~mm}$ sodium phosphate; $\mathrm{pH} 7.4$ ) several times by sedimentation/ resuspension. Sedimented cells, resuspended in phosphate-buffered saline ( $10 \mathrm{~mm}$ sodium phosphate, $150 \mathrm{~mm} \mathrm{NaCl}$ ), were mixed with previously emulsified complete (and then incomplete) Freund's adjuvant Intradermal immunizations were carried out at 2 week intervals, and bleeding initiated at 6 weeks; thereafter, immunization and bleeding alternated weekly.

Additional polyclonal antiserum were developed in rabbits using isolated plasmalemmal fractions prepared from cultures composed of type 1 and from cultures of type 2 astrocytes. On the basis of immunofluorescent and immunoblotting criteria these antisera appeared less promising than antisera developed against aldehyde-fixed cells for the identification of astroglial cell membrane proteins that may participate in cell migration events.

The following antibodies have been produced and characterized as described previously: Rat 401, the gift of Dr. S. Hockfield (Hockfield and McKay, 1985); RCl, the gift of Dr. M. Yamamoto (Edwards et al., 1990); RIP, the gift of Drs. B. Friedman and J. Black (Friedman et al., 1989).

Immunocytochemical procedures. For localizing antigens by indirect immunofluorescence, glial cells, grown on uncoated glass coverslips, were rinsed with tissue culture medium and fixed with $3 \%$ formaldehyde (freshly prepared from paraformaldehyde) in 120 mm sodium phosphate $\left(37^{\circ} \mathrm{C}, 20 \mathrm{~min}\right)$. Processing for indirect immunofluorescence was performed as described (DeCamilli et al., 1983). The distribution of antigens was visualized by use of the secondary antibodies rhodamineconjugated goat $\alpha$-rabbit IgG, or fluorescein-conjugated goat $\alpha$-mouse IgGs. Coverslips were mounted in a freshly prepared solution containing $10 \mathrm{~mm}$ sodium phosphate $(\mathrm{pH} 7.4), 150 \mathrm{~mm} \mathrm{NaCl}, 70 \%$ glycerol, and $1 \mathrm{mg} / \mathrm{ml} p$-phenylenediamine. Rhodamine-phalloidin, prepared in methanol and dried down under $\mathrm{N}_{2}$, was utilized for labeling filamentous actin. Glial cells, grown on uncoated glass coverslips, were fixed in $3 \%$ formaldehyde, permeabilized with acetone $\left(-20^{\circ} \mathrm{C}\right)$ or Triton X-100 $(0.1 \%)$, and stained with a $1: 50$ dilution of rhodamine-phalloidin according to the manufacturer's instructions. Cells were viewed through a Zeiss Axiophot microscope equipped with epifluorescent optics and photographed using Kodak Tmax 100 film. 
Isolation of membrane and soluble fractions. Tissue culture cells were rinsed with homogenization medium ( $40 \mathrm{~mm}$ Tris, $\mathrm{pH} 7.4,1 \mathrm{mM} \mathrm{MgCl}$ ) and scraped into a small volume of the same medium supplemented with $1 \mu \mathrm{g} / \mathrm{ml}$ each of leupeptin, pepstatin A, antipain, aprotinin, 0.4 mu phenylmethylsulfonyl fluoride, and $0.005 \%$ DNase. Cell homogenization was carried out using a tight-fitting Dounce homogenizer. Centrifugation ( $3 \mathrm{~min}$ at $50 \mathrm{~g}$ ) yiclded a supernatant, which was aspirated and saved, and a sediment containing nuclei and unbroken cells. The latter was resuspended in the original volume of homogenization medium, and homogenization and centrifugation were repeated $(3 \times$ total). The supernatants were combined, adjusted to $1.5 \mathrm{~mm}$ EDTA, and filtered through $100 \mu \mathrm{m}$ nylon mesh. Centrifugation (45 min at $9.0 \times 10^{4}$ $g$ in a Beckman type 70 ti rotor) produced a crude membrane fraction. The crude membrane fraction was resuspended in a salt solution (10 mM Tris, $150 \mathrm{~mm} \mathrm{NaCl}, 5 \mathrm{~mm}$ EDTA; pH 7.4) with subsequent centrifugation (condition as above) generating a membrane fraction devoid of most soluble proteins. In order to remove more tightly associated proteins, membrane fractions were treated with sodium carbonate (100 mм sodium carbonate, $50 \mathrm{~mm} \mathrm{KCl,} 5 \mathrm{~mm}$ EDTA pH 11; $30 \mathrm{~min}$ at $4^{\circ} \mathrm{C}$ ) (Fujiki et al., 1982), diluted in $\mathrm{dH}_{2} \mathrm{O}$, and collected by centrifugation ( $45 \mathrm{~min}$ at $1.2 \times 10^{4} \mathrm{~g}$ in a Bcckman type 70 ti rotor).

Preparation of membrane fractions obtained from embryonic and adult tissues was carried out as described for tissue culture cells except that tissues were disrupted by using five passes at $1300 \mathrm{rpm}$ in a Brendler Teflon-glass homogenizer.

Nuclei were prepared from adult cerebral cortex according to procedures described by Davis and Blobel (1986) and a soluble protein fraction was obtained by salt extraction (Andrews and Faller, 1991). Soluble cytoplasmic protein fractions were obtained by sedimentation (60 min at $1.2 \times 10^{5} \mathrm{~g}$ in a Beckman type 70 ti rotor) of cell homogenates prepared by hypotonic lysis ( $1 \mathrm{~mm} \mathrm{NaHCO}$, pH 7.2) of cortical astroglial cells and adult cerebral cortex and cerebellum. For preparation of tissue culture supernatants, primary astroglial cell cultures were grown in chemically defined medium (DMEM supplemented with $1 \%$ HL1) for $5 \mathrm{~d}$. Subscquently, the medium was collected and concentrated by ultrafiltration.

Polyacrylamide gel electrophoresis and immunoblotting. For one-dimensional SDS-PAGE analyses, reduced protein samples $(40 \mathrm{~mm}$ dithiothreitol) were resolved in $8.5 \%$ acrylamide gels in Laemmli (1970) buffer system. Two-dimensional PAGE (isoelectric focusing, SDS) was carried out as described previously (Cameron et al., 1986). Membrane samples $(75 \mu \mathrm{g})$ were solubilized in $1 \%$ SDS and $40 \mathrm{~mm}$ dithiothreitol prior to isoelectric focusing. Second-dimension resolving gels were $8.5 \%$ acrylamide prepared in the Laemmli (1970) buffer system. Protein was determined according to Markwell et al. (1978) using bovine serum albumin as a standard.

Fractionated polypeptides were electrophoretically transferred to nitrocellulose according to the procedure of Towbin et al. (1979). Immunoblots were incubated in blocking buffer $(5 \%$ nonfat dry milk, 10 mм Tris, $150 \mathrm{~mm} \mathrm{NaCl}$; $\mathrm{pH} \mathrm{7.5)} \mathrm{for} 60 \mathrm{~min}$, and subsequently overnight in blocking buffer containing primary antiserum (1:1000 dilution). Bound antibodies were detected using secondary biotinylated goat $\alpha$-rabbit antibodies $(1: 2000,90 \mathrm{~min})$ and subsequently a streptavidin-peroxidase conjugate $(1: 1000,90 \mathrm{~min})$. Immunoblots were processed for enhanced chemiluminescence according to the manufacturer's instructions and exposed to Kodak XAR film at room temperature for a time sequence of $1-15 \mathrm{~min}$

Glycosylation analyses. Peptide:N-glycosidase F digestion for the removal of simple and complex $N$-linked oligosaccharide chains was carried out as follows. Samples of membrane $(100 \mu \mathrm{g})$ were reduced and denatured $\left(40 \mathrm{~mm}\right.$ dithiothreitol, $\left.0.5 \% \mathrm{SDS} ; 90^{\circ} \mathrm{C}, 3.5 \mathrm{~min}\right)$. The reaction volume was adjusted to $75 \mu \mathrm{l}$ volume and contained, at final concentration, $100 \mathrm{~mm}$ sodium phosphate $\mathrm{pH} 8.6,2.0 \%$ Nonidet P-40, and enzyme units as indicated in the text. Following incubation $(12 \mathrm{hr}$, $37^{\circ} \mathrm{C}$ ), digested samples were diluted in SDS sample buffer and processed for one-dimensional SDS-PAGE and immunoblutling.

Chemical deglycosylation by trifluoromethanesulfonic acid (TFMS) was carried out using an isolated salt-washed membrane fraction according to procedures described by Horvath et al. (1989). Aliquots of membrane $(100 \mu \mathrm{g})$ were extracted in ethanol : ethyl ether $(50: 50 \mathrm{v} / \mathrm{v})$ prior to deglycosylation processing.

Affinity purification of polypeptide-specific antibodies. Astroglial membrane polypeptides were resolved by preparative SDS-PAGE, electrophoretically transferred onto a nitrocellulose sheet, and processed for immunoblot analysis. Edge strips, excised and processed for antibody detection, were used to identify the position of antigens of interest. Horizontal strips of nitrocellulose were removed and bound antibodies desorbed by incubation in low pH buffer $(50 \mathrm{~mm}$ glycine, $150 \mathrm{~mm} \mathrm{NaCl}$ pH 2.2) four times. Eluates, neutralized immediately by addition of 1 M Tris, were concentrated by ultrafiltration (Centicon 10,000, Amicon). Concentrated antibody solutions were supplemented with bovine serum albumin at $100 \mu \mathrm{g} / \mathrm{ml}$ and used for subscquent immunoblot and immunofluorescent analyses.

Disruption of the cytoskeleton. Microtubules were disrupted by incubation of cells for $120 \mathrm{~min}$ at $37^{\circ} \mathrm{C}$ in serum-free medium containing $10 \mu \mathrm{g} / \mathrm{ml}$ nocodazole, diluted from a $10 \mathrm{mg} / \mathrm{ml}$ nocodazole stock solution prepared in dimethyl sulfoxide (DMSO). Subsequently, cells were rinsed rapidly in serum-free medium, fixed in $3 \%$ formaldehyde, and processed for indirect immunofluorescent analyses as described. Alternatively, cell dishes were placed at $4^{\circ} \mathrm{C}$ for $60 \mathrm{~min}$ prior to aldehyde fixation at $4^{\circ} \mathrm{C}$. The actin cytoskeleton was disrupted by incubation of cells for $60-120 \mathrm{~min}$ at $37^{\circ} \mathrm{C}$ in serum-free medium supplemented with $5 \mu \mathrm{g} / \mathrm{ml}$ cytochalasin B or $1 \mu \mathrm{g} / \mathrm{ml}$ cytochalasin D, diluted from a 10 $\mathrm{mg} / \mathrm{ml}$ stock solution prepared in DMSO. Cells were fixed and processed for indirect immunofluorescent analyses as described above.

\section{Results}

Of the several polyclonal rabbit antisera developed to identify polypeptides that may participate in glial-neuronal cell interactions, one (D4), developed against formaldehyde fixed type 1 cerebellar astroglial cells, immunolabeled the extracellular surface of cortical and cerebellar astroglial and radial glial cells in a patchy pattern. In the present study, we have evaluated the cellular and subcellular distribution of these cell surface patches or microdomains and determined, among the spectrum of antigens recognized by the polyclonal antiserum, those antigens that contribute to the formation of the microdomains.

\section{Distribution of andigens in glial and neuronal prirnary cell cultures}

Indirect immunofluorescence was used to determine the cellular and subcellular distribution of antigens on aldehyde-fixed primary cell cultures of cortical and cerebellar type 1 astrocytes. Cell cultures were processed in the presence or absence of Triton $\mathrm{X}-100$, in order to distinguish between an intracellular or a plasmalemmal surface distribution of antigens, respectively. The predominant cell class (90-95\%) present in mixed glial cell cultures comprised cells of an epithelial-like morphology and an antigen phenotype of $\mathrm{GFAP}^{+}$, vimentin ${ }^{+}, \mathrm{RCl}^{+}$, and $\mathrm{Rat} 40 \mathrm{I}^{+}$ (data not shown), a morphology and antigen composition consistent with type 1 astrocytes (Raff, 1989; Cameron and Rakic, 1991). Type 1 astroglial cells, obtained from cerebellum and reacted with polyclonal antiserum to GFAP are shown in Figure $1 A$. Analyses of nonpermeabilized cerebral cortical and cerebellar type 1 astrocytes reacted with the D4 antiserum demonstrated that immunoreactivity was distributed as prominent, intensely fluorescent patches or microdomains on the extracellular plasmalemmal surface (Fig. $1, B, C$ and $E, F$, respectively). In most cases these microdomains circumscribed the cell periphery in a staggered array, although in some instances $(\sim 5 \%$, $n=5000$ ), microdomains were aligned in register at sites of glial cell-glial cell apposition. In addition to the surface microdomains, we observed a generalized faint immunostaining of the plasma membrane as well as small puncta distributed randomly across the cell surface. Quantitative analyses of the surface microdomains indicate an average surface area of $21 \mu \mathrm{m}^{2}$ (range $2.0-90 \mu \mathrm{m}^{2}$, SD $16 ; n=400$ ) for astroglial cells prepared from cerebral cortex, and $17 \mu \mathrm{m}^{2}$ (range $0.4-230 \mu \mathrm{m}^{2}$, SD 20; $n=1600$ ) for astroglial cells prepared from cerebellum. 

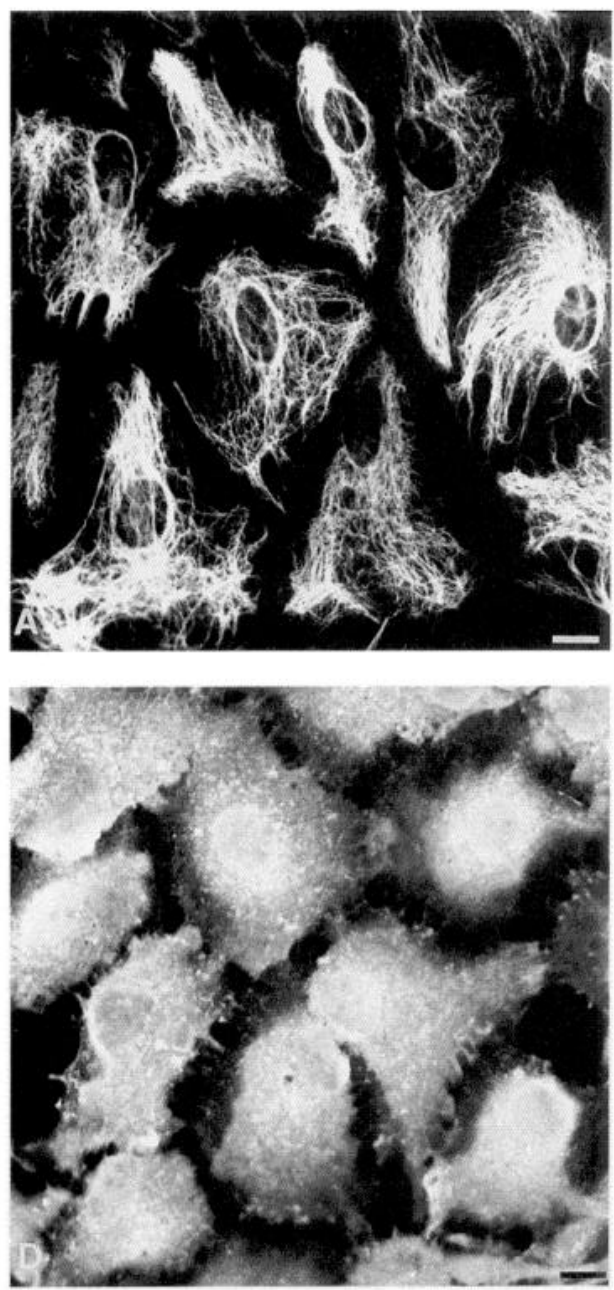
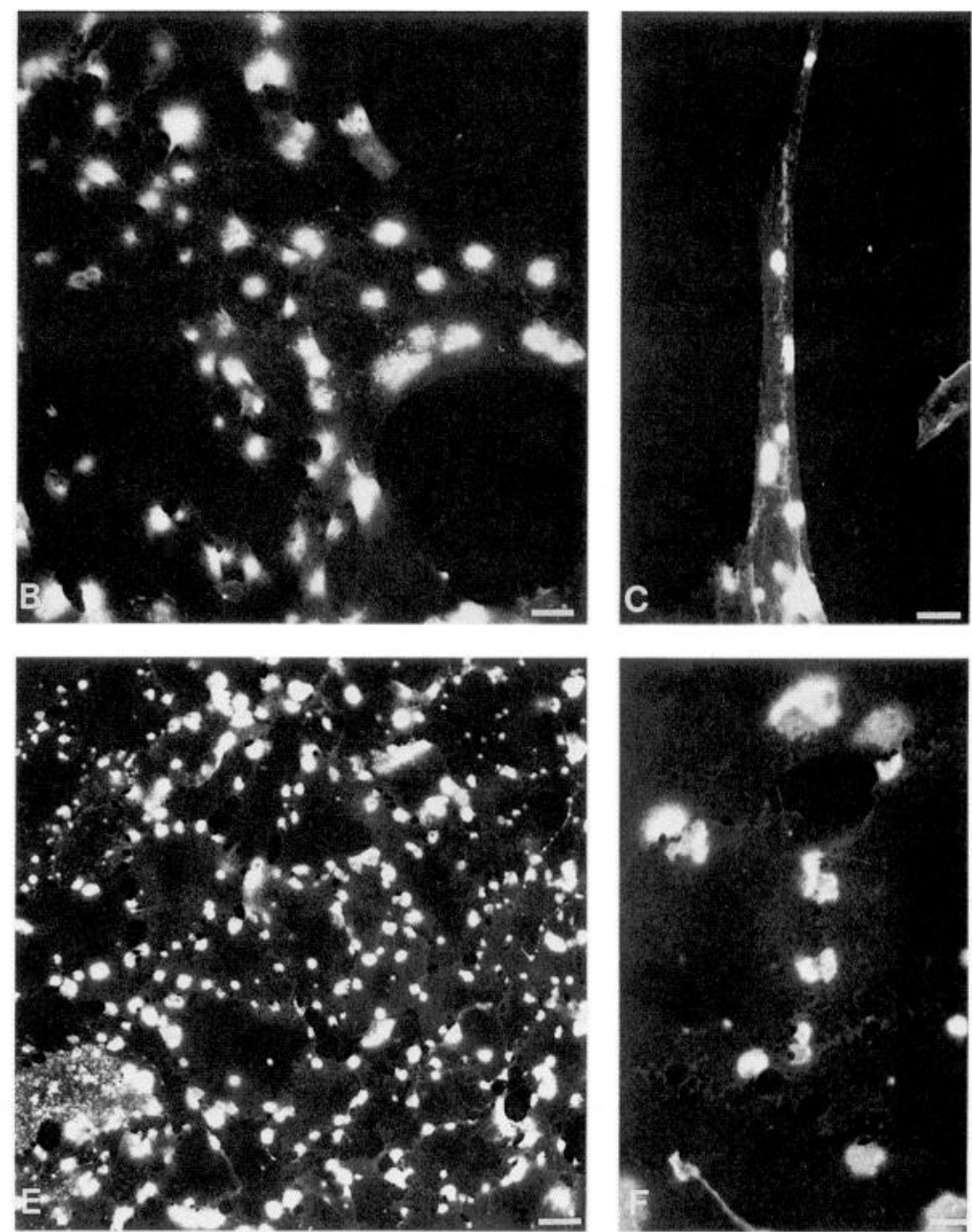

Figure 1. Indirect immunofluorescent staining of cultured cerebral cortical $(A-C)$ and cerebellar $(D-F)$ type 1 astrocytes using polyclonal antiserum to GFAP $(A)$ and polyclonal antiserum D4 $(B-F)$. In nonpermeabilized cerebral cortical $(B$ and $C)$ and cerebellar $(E$ and $F)$ astroglial cells, D4 immunoreactivity is detected as large fluorescent patches at the plasmalemmal surface. In contrast, in permeabilized cerebral cortical or cerebellar astroglial cells $(D)$, D4 immunoreactivity is detected as small fluorescent puncta scattered throughout the cell as well as in association with the nucleus and the cytoplasm. Scale bars: $A, 12 \mu \mathrm{m} ; B, 9 \mu \mathrm{m} ; C$ and $D, 10 \mu \mathrm{m} ; E, 19 \mu \mathrm{m} ; F, 8 \mu \mathrm{m}$.

The images obtained for nonpermeabilized cortical and cerebellar type 1 astrocytes were in distinction to those observed when D4 immunostaining was carried out in the presence of permeabilizing reagents (Fig. $1 D$ ). In these cases, the immunostaining pattern was characterized by small fluorescent puncta distributed throughout a diffusely fluorescent cytoplasm. Further, immunoreactivity appeared to be concentrated at the level of the nuclear envelope and within the nuclear matrix.

Several lines of evidence, obtained from both in vivo and in vitro analyses, indicate that radial glial cells undergo a morphological transformation into astrocytic cell classes (Schmechel and Rakic, 1979; Levitt and Rakic, 1980; Hatten, 1985, 1987; Rickman et al., 1987; Culican et al., 1990; Gasser and Hatten, 1990a). When cultured in the absence of neuronal cell contact, radial glial cells assume a flattened, epithelial-like morphology that is indistinguishable from type 1 astrocytes. Accordingly, we prepared primary cell cultures enriched in radial glial cells from embryonic day 18 hippocampus and neonatal day 1 cerebellum. Radial glial cells displayed elongated cellular profiles and comprised an antigen phenotype $\left(\mathrm{RCl}^{+}, \mathrm{Rat}^{4} 401^{+}, \mathrm{GFAP}^{+}\right.$, vimentin ${ }^{+}$; data not shown) similar to that described in previous analyses (Levitt and Rakic, 1980; Hockfield and McKay, 1985; Rickmann et al., 1987; Culican et al., 1990; Edwards et al., 1990; Gasser and Hatten, 1990a). When nonpermeabilized radial glial cell cultures were analyzed, D4 immunoreactivity was detected as surface patches or microdomains (Fig. 2). Although the microdomains appear to be localized to variable positions at the cell surface, the majority could be categorized into two groups: microdomains that occupied a continuous segment of a radial glial cell process (Fig. $2 B$ ), and microdomains that appeared as small foci positioned around the periphery of a radial glial cell process (Fig. $2 C$ ). In permeabilized radial glial cells, D4 immunostaining was detected throughout the cell without resolution of intracellular structures (Fig. $2 A$ ).

To determine if the microdomains were expressed by all glial cell phenotypes, primary cell cultures of process-bearing astroglial cells and oligodendrocytes were processed for indirect immunofluorescence analyses. Process-bearing astrocytes, which comprise $5-10 \%$ of cells present in type 1 astrocyte cultures, were immunopositive for GFAP (Fig. $3 G$ ) but had negligible levels of expression for the $\mathrm{RCl}$, Rat 401, and vimentin antigens (data not shown). When nonpermeabilized cell cultures con- 
taining process-bearing astrocytes were reacted with D4 antiserum, only a small number of process-bearing astrocytes were immunoreactive. In all cases, immunoreactivity was limited to a perinuclear position (Fig. 3I). A monoclonal antibody, RIP (Freidman et al., 1989), was used to identify all stages of oligodendrocyte differentiation present in primary cell cultures (Gard and Pfieffer, 1990), bipolar progenitor cells, and maturing oligodendrocytes that display intermediate and complex morphologic features (Fig. 3A-C). Double-label immunofluorescence analyses carried out on oligodendrocyte cultures revealed distinct GFAP- and RIP-immunopositive cell populations. In no case did we observe an antigenic overlap. Significantly, D4 immunoreactivity was not detected above preimmune controls in nonpermeabilized oligodendrocyte cultures (Fig. $3 E, F$, respectively). In contrast, both process-bearing astrocyte (Fig. $3 H$ ) and oligodendrocyte (Fig. $3 C$ ) cultures that were processed for indirect immunofluorescence analyses in the presence of permeabilizing agents displayed D4 immunoreactivity in a cytoplasmic and nuclear distribution similar to that observed for other permeabilized cell types.

To determine if the D4-positive microdomains were expressed exclusively by type 1 astroglial and radial glial cells, we immunostained preparations of primary neuronal cell cultures prepared from embryonic day 18 rat hippocampi and postnatal day 8 rat cerebella. In both permeabilized and nonpermeabilized low-density cell cultures of hippocampal and cerebellar granule neurons, D4 immunoreactivity was distributed uniformly along axonal, somal, and dendritic plasma membrane compartments (Fig. $4 A, B$ ). We have not observed microdomains aligned at sites of neuronal-neuronal cell contact. However, on occasion, when nonpermeabilized, high-density cell cultures of hippocampal neurons were reacted with D4 antiserum, immunostaining was observed as intermittent fluorescent segments that were associated exclusively with the axonal plasma membrane; dendrites and cell bodies were immunonegative (data not shown). We have not determined if the restriction of D4 immunoreactivity to the axonal plasma membrane parallels synaptogenesis as has been shown for several neuronal cell adhesion proteins (e.g., Pourquie et al., 1992).

Last, we carried out indirect immunofluorescence analyses to evaluate the possibility that the identified microdomains might play a role in selective glial-neuronal cell adhesion and/or cell migration events. Toward this aim, single cell dissociates were prepared from postnatal day 3 rat cerebella and maintained in culture for 48-72 hr. Elongated glial cell processes in association with cells characteristic of migrating neuronal cells (Edmondson and Hatten, 1987; Fishell and Hatten, 1991) could be identified readily following the removal of most loosely bound cells or cell aggregates. In nonpermeabilized cell cultures, D4 immunoreactivity was detected at the site where the neuronal cell soma was in contact with the cell surface of an elongated glial cell fiber (Fig. 5A,B). For most cell pairs analyzed, immunoreactivity associated with the neuronal cell soma was limited exclusively to the contact region (Fig. 5A). However, for a limited number of cell pairs, immunoreactivity, although highly concentrated at the membrane contact interface, was detected at the neuronal cell surface in a partially polarized distribution (Fig. $5 B$ ). Immunoreactivity associated with the contact site appears to be contributed along the entire length by both the neuronal and the glial cell surfaces (Fig. $5 B$ ). In contrast to the distribution of immunoreactivity obtained for all migrating neurons, nonmigratory neurons, adhered at the level of the glial cell soma or

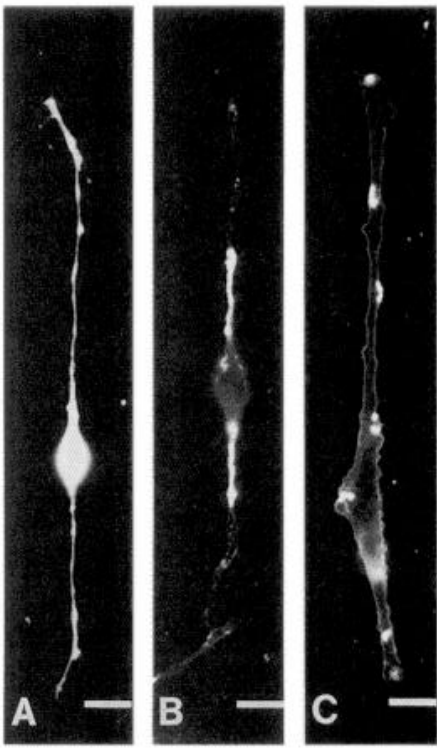

Figure 2. Indirect immunofluorescent staining of radial glial cells in cell cultures using polyclonal antiserum D4. In permeabilized cell cultures containing radial glial cells, immunoreactivity is detected throughout the cell without resolution of individual cell structures $(A)$. In contrast, in nonpermeabilized cell cultures, immunoreactivity is observed at the plasmalemmal surface of radial glial cells either as fluorescent segments along the elongated processes $(B)$ or as small fluorescent foci distributed around the cell periphery $(C)$. Scale bars: $A, 18 \mu \mathrm{m} ; B, 14$ $\mu \mathrm{m} ; C, 13 \mu \mathrm{m}$.

along their elongated process, consistently showed a uniform immunofluorescence of the plasma membrane (Fig. 5A,B). This pattern is similar to the results observed for purified hippocampal and cerebellar neurons cultured as monolayers in the absence of astroglial cells (Fig. $4 A, B$ ) or growing as polarized neurons on top of a bed of type 1 astrocytes (data not shown). We have not determined directly whether the two differing distributions could reflect successive stages of contact development or contact maturation during neuronal cell migration. Lastly, additional small foci of immunoreactivity are detected along the elongated glial cell process in advance of the neuronal cell soma. Although consistent with the positioning of the leading process, definitive proof of this possibility will require more extensive microscopic analyses.

\section{Identification of antigens expressed by type 1 astrocytes in primary culture}

To determine the spectrum of plasmalemmal polypeptides recognized by the D4 antiserum, membrane polypeptides obtained from cortical and cerebellar type 1 astroglial cell cultures were resolved by one- and two-dimensional SDS-PAGE and processed for immunoblot analysis. The antigen profiles determined for type 1 astroglial cells obtained from cerebral cortex or cerebellum are nearly identical (Fig. $6 B, C$ ). Each profile comprised $\sim 15$ species with electrophoretic mobilities corresponding to apparent molecular masses ranging from 30 to $300 \mathrm{kDa}$ and isoelectric points between $\mathrm{pH} 4$ and 8.5. The number and distribution of polypeptides by apparent molecular mass are consistent with those obtained by resolution of polypeptides in one dimension (Fig. 6A,D). Electrophoretic mobilities of identified antigens were not affected by the absence or presence of disulfide bond reduction, with or without alkylation (data not shown). 

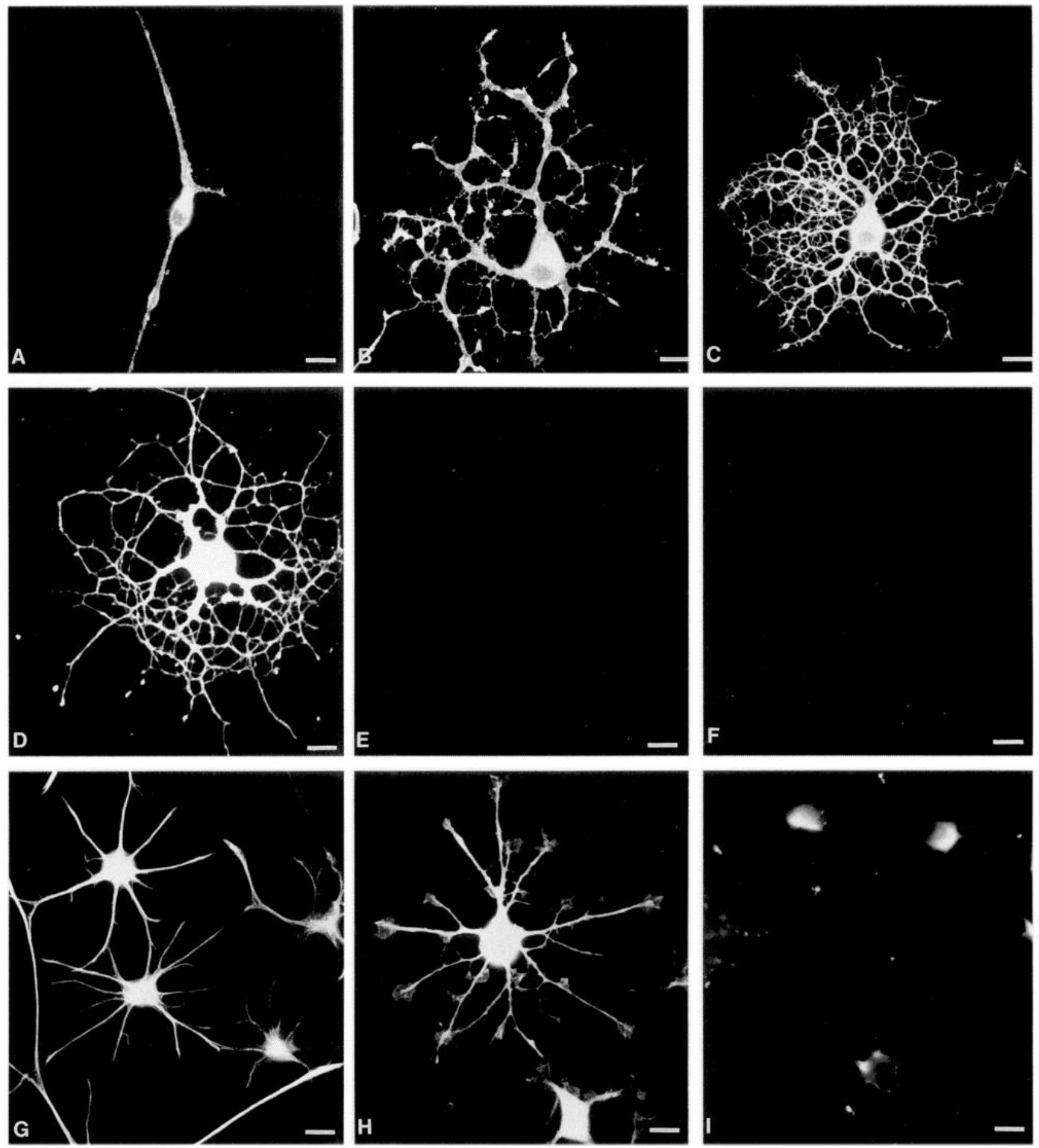

Figure 3. Indirect immunofluorescent analyses of primary cell cultures containing oligodendrocytes and process-bearing astroglial cells. All cell differentiation stages present during oligodendrocyte maturation-bipolar progenitor cells $(A)$ and maturing oligodendrocytes that display intermediate $(B)$ and complex morphologic features $(C)$-could be recognized using the monoclonal antibody RIP. Permeabilized oligodendrocytes that had been reacted with the D4 antiserum showed an intense fluorescence throughout the cell $(D)$, a fluorescent image similar to that obtained for other permeabilized glial cells. In nonpermeabilized cultures of oligodendrocytes $(E), \mathrm{D} 4$ immunoreactivity was not detectable above preimmune controls $(F)$. Process-bearing astrocytes were identified using polyclonal antiserum to GFAP $(G)$. In permeabilized cell cultures containing processbearing astrocytes, D4 immunoreactivity was distributed throughout the cell $(H)$, while in nonpermeabilized cell cultures of process-bearing astroglial cells, D4 immunoreactivity was limited to a perinuclear region $(I)$. Scale bars: $A-C, H, I, 11 \mu \mathrm{m} ; D-G, 10 \mu \mathrm{m}$. 

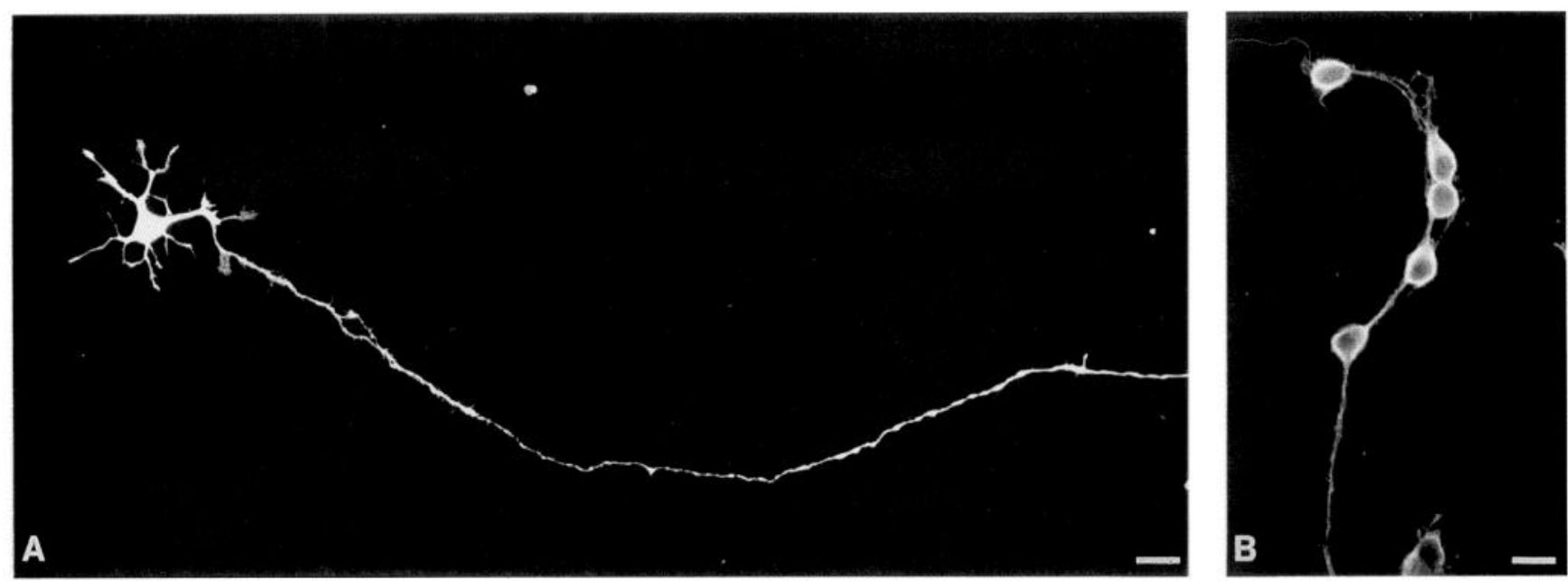

Figure 4. Indirect immunofluorescent analyses of primary neuronal cell cultures using the polyclonal antiserum D4. In primary cultures of hippocampal neurons, $5 \mathrm{~d}$ in vitro $(A)$, and isolated cerebellar granule neurons, $3 \mathrm{~d}$ in vitro $(B)$, D4 immunoreactivity was detected along all plasmalemmal surfaces. Permeabilized and nonpermeabilized neuronal cell preparations showed analogous distributions of D4 immunoreactivity. Scale bars: $A, 20 \mu \mathrm{m} ; B, 11 \mu \mathrm{m}$.

\section{Identification of antigens expressed during development of cerebral cortex}

Detailed comparative analyses of immunoblots prepared by twodimensional SDS-PAGE of membrane fractions for cerebral cortices were carried out to determine if any of the astroglial cell antigens were expressed in vivo at periods when postmitotic neuronal cell migration is a prominent morphogenetic event.

Immunoblots prepared for cerebral cortical membrane polypeptides obtained from embryonic day 12 and 18, birth (day 0 ), neonatal day 12 , and adult cerebral cortices show that four sets of antigens appear to be differentially expressed at the various developmental ages examined (Fig. $7 A-E$ ). Antigen set A, composed of two protein doublets of apparent molecular mass 46-52 kDa, was detected in immunoblots prepared for embryonic days 12 and 18 , but becomes undetectable at later ages. Antigen set B, comprising three protein species of apparent molecular weight ranging from 54 to $57 \mathrm{~K}$, was detected initially at embryonic day 18 and, thereafter, was detected at reduced levels. Antigen set $\mathrm{C}$, made up of two polypeptides of similar apparent molecular weight, $\sim 72 \mathrm{~K}$, was observed at embryonic day 18 and remained detectable through adulthood. Last, antigen set $\mathrm{D}$, comprising a single diffuse polypeptide in excess of $200 \mathrm{~K}$ apparent molecular weight, was initially detected at embryonic day 12. Antigen set D increased to a maximal level of expression during early postnatal development and, subsequently, decreased to a negligible level of expression in adulthood. To determine if any of the antigens detected in cerebral cortical tissue were potentially neural specific, a carbonate washed membrane fraction was prepared from adult liver and associated polypeptides resolved by two-dimensional SDS-PAGE. Immunoblot analysis indicated that only antigen sets $\mathrm{B}$ and $\mathrm{C}$ were detected in liver tissue (Fig. $7 F$ ).

Comparison of the immunoblots obtained for cerebral cortical tissues with those obtained for type 1 astroglial cell membranes reveals an antigen composition that is similar with two notable exceptions. First, the polypeptide of apparent molecular mass $100-120 \mathrm{kDa}$ and isoelectric point stuttered between 4.3 and 6.6 identified in immunoblots of astroglial cell membrane is absent from all immunoblots prepared from cerebral cortical tissues. Second, the antigens of apparent molecular mass $\sim 72$ $\mathrm{kDa}($ set $\mathrm{C}$ ) identified in immunoblots of cerebral cortical tissues are not detected in immunoblots of astroglial cell membrane (compare Figs. 6, 7).

\section{Identification of the polypeptide(s) that comprises the microdomains}

To determine which antigens contributed to the formation of the surface microdomains, we prepared affinity-purified antibodies to individual astroglial cell membrane polypeptides. To this end, membrane fractions isolated from cerebral cortical astroglial cell cultures were resolved by preparative one-dimensional SDS-PAGE and processed for immunoblot analyses. Antibodies recovered from appropriate polypeptide marker regions were used for further immunoblot and immunocytochemical analyses. Of the 10 affinity-purified antibodies screened by indirect immunofluorescence, only one identified cell surface microdomains analogous to those observed for the unfractionated D4 antiserum (Fig. $8 B, C$ ). When this antibody was used to probe immunoblots of cortical astroglial cell membrane polypeptides resolved by one-dimensional SDS-PAGE, a prominent doublet band of apparent molecular mass $48 \mathrm{kDa}$ was detected (Fig. $8 A$ ). A faint doublet band of apparent molecular mass $52 \mathrm{kDa}$ could be detected on overexposed films and likely reflects an antibody contaminant as a consequence of similar electrophoretic mobilities in one-dimensional SDS-PAGE. Notably, the $48 \mathrm{kDa}$ antigens detected in this analysis correspond to the polypeptides defined by the antigen set $\mathrm{A}$ in immunoblot analyses of cerebral cortical tissues (Fig. 7).

\section{Characterization of the 100-120 kDa antigen}

As several analyses indicated that the $100-120 \mathrm{kDa}$ antigen, which is detected only in astroglial cells maintained in culture, might also be a component of the cell surface microdomains, we carried out a more detailed characterization of the 100-120 $\mathrm{kDa}$ antigen. The affinity-purified antibody to the $100-120 \mathrm{kDa}$ antigen, when reblotted onto cortical astroglial membrane polypeptides, recognized predominantly the 100-120 kDa polypeptide, but also, at a low level, a protein of apparent molecular mass $130 \mathrm{kDa}$ with a corresponding isoelectric point of ap- 

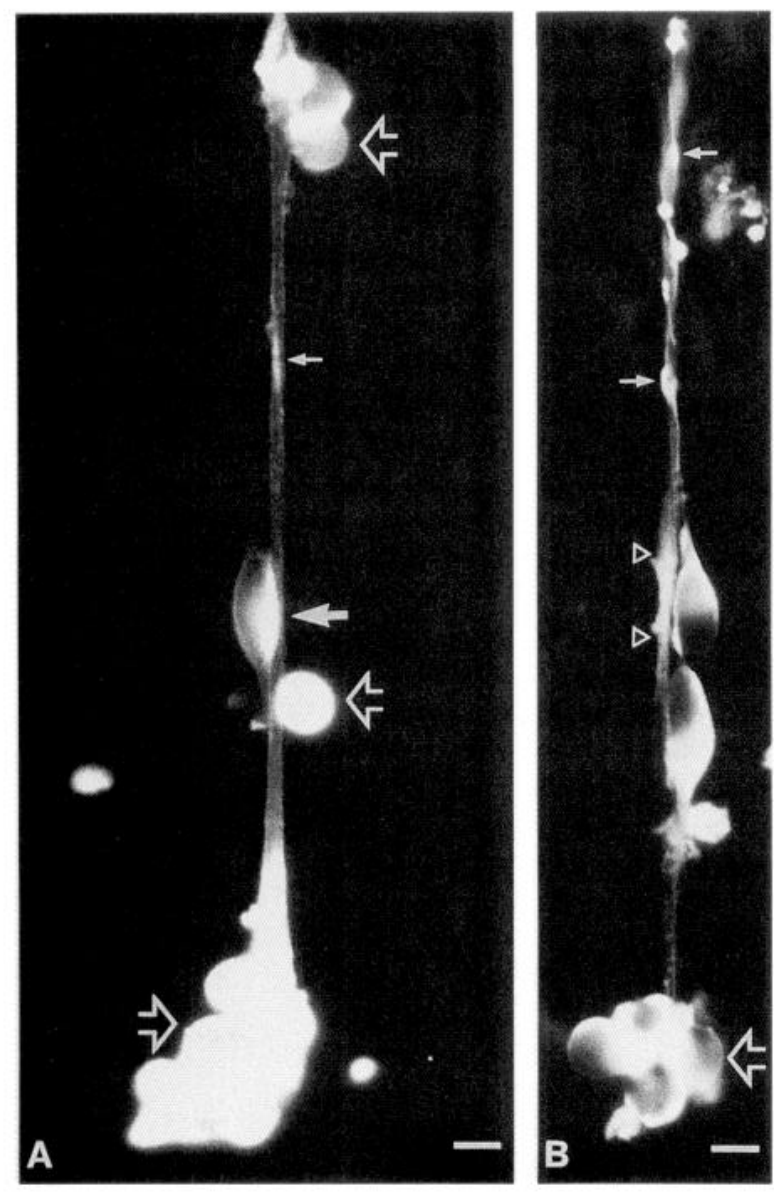

Figure 5. Indirect immunofluorescent staining of migrating cerebellar granule neuron using polyclonal antiserum D4. In cell dissociates of neonatal cerebellum or in reconstituted migrating cell preparations, granule neurons migrating along the elongated processes of glial cells can be observed readily. In all cell preparations examined, immunofluorescence is concentrated at the site of contact between the neuronal cell soma and the elongated glial cell process. For most cell pairs, immunoreactivity was restricted to the site of contact (large solid arrow, $A)$. In a few cell pairs, immunoreactivity was not confined solely to the site of contact $(B)$. Although the microdomain structure contributed by the astroglial cell was restricted to the site of contact (open arrowheads, $B)$, migrating neurons displayed a partially polarized distribution of immunoreactivity at the plasma membrane. In contrast, the nonmigrating neurons that adhere to the processes or soma of elongated glial cells display a uniform fluorescence of the plasmalemmal surface (open arrows). Additional foci of immunoreactivity (small solid arrows) are detected in advance of the neuronal cell soma and may ultimately correspond to the leading process. Scale bars, $7 \mu \mathrm{m}$.

proximately 6.8 (Fig. $9 A$ ). In contrast, when blots of membrane fractions prepared from cells that did not express the 100-120 $\mathrm{kDa}$ antigen -isolated cerebellar granule neurons, PC-12 cells, and $\mathrm{C} 6$ glioma cells-were probed using the affinity-purified 100-120 kDa antibodies (Fig. 9B-D), three polypeptide species were detected with electrophoretic mobilities corresponding to apparent molecular masses of $72 \mathrm{kDa}, \sim 72 \mathrm{kDa}$, and $130 \mathrm{kDa}$. The $72 \mathrm{kDa}$ antigen doublet had molecular mass and isoelectric point features identical to those identified for antigen set $\mathrm{C}$ in brain and liver tissues (compare with Fig. 7). Accordingly, we prepared affinity-purified antibodies to the $72 \mathrm{kDa}$ polypeptides by antibody desorption from immunoblots prepared following fractionation of liver plasma membrane polypeptides by pre- parative one-dimensional SDS-PAGE. Indirect immunofluorescent analysis demonstrated that the affinity-purified antibodies to the $72 \mathrm{kDa}$ polypeptides labeled cell surface microdomains on type 1 cortical astrocytes and radial glial cells similar to those detected by use of the unfractionated polyclonal D4 antiserum (Fig. $8 D, E$ ). When the affinity-purified $72 \mathrm{kDa}$ antibodies were used to probe nitrocellulose blots of cortical astroglial cell membrane polypeptides that had been resolved in two dimensions, the $130 \mathrm{kDa}$ polypeptide and the $72 \mathrm{kDa}$ polypeptides were detected, albeit at a low level (Fig. $9 E$ ). Surprisingly, however, affinity-purified $72 \mathrm{kDa}$ antibodies did not detect the 100-120 kDa polypeptide in immunoblots of cortical astroglial cell membranes. Evidently, the $130 \mathrm{kDa}$ antigen and the $72 \mathrm{kDa}$ antigens are immunologically related, as affinitypurified antibodies to each individual polypeptide cross-react.

To determine if glycosylation could account for the observed difference in apparent molecular weight between the 100-120 $\mathrm{kDa}$ and $72 \mathrm{kDa}$ polypeptides, isolated cortical astroglial cell membrane polypeptides were deglycosylated using N-glycosidase F. Immunoblot analysis of polypeptides resolved by onedimensional SDS-PAGE indicated that the removal of N-linked sugars was accompanied by an en bloc shift in electrophoretic mobility corresponding to $\sim 20 \mathrm{kDa}$, or 7-10 N-linked sugar chains (assuming 2000-3000 kDa/chain) (Fig. 10A). As N-linked deglycosylation appeared incomplete (we have not obtained evidence that suggests the presence of serine- or threonine-linked oligosaccharides), a harsher, chemical deglycosylation analysis of isolated cortical astroglial cell membrane was carried out using TFMS. Immunoblot analyses indicated that TFMS treatment resulted in the loss of the 100-120 kDa antigen and the appearance of a novel polypeptide band with an apparent molecular mass of $\sim 72 \mathrm{kDa}$ (arrowhead in Fig. 10B; compare to Fig. 6A). Affinity-purified antibodies to the $72 \mathrm{kDa}$ antigen, but not the 100-120 kDa antigen, could detect the apparent deglycosylated polypeptide by immunoblot analyses (data not shown).

To assess the possibility that the $100-120 \mathrm{kDa}$ antigen reflects a posttranslational glycosylation of the $72 \mathrm{kDa}$ antigen in vitro, membrane fractions prepared from cortical astroglial cells maintained in vitro for between 1 and $21 \mathrm{~d}$ were resolved by onedimensional SDS-PAGE and processed for immunoblot analysis (Fig. 10C). Although minor quantitative differences among the polypeptide profiles are evident, the data show that the 100 $120 \mathrm{kDa}$ antigen is detected initially at approximately day $3 \mathrm{in}$ vitro. Thereafter, increased levels of the 100-120 kDa polypeptide are detected. Interestingly, preliminary analyses of neuronal-glial cell cocultures indicate that the expression of the 100 $120 \mathrm{kDa}$ antigen is correlated with the growth of astroglial cells in the absence of neuronal cells. Addition of purified neuronal cell populations to isolated astroglial cells prevents or subsequently reduces the overall level of expression of the 100-120 $\mathrm{kDa}$ antigens (data not shown).

\section{Expression of microdomain antigens during development of cerebellum}

To determine if the microdomain antigens could correlate to periods of active neuronal cell migration in vivo, we determined the antigen profile for cerebellar tissues. To this end, carbonatewashed membrane fractions were obtained from adult, neonatal day 15 , and neonatal day 5 cerebella. Polypeptides were resolved by two-dimensional SDS-PAGE and processed for immunoblot analysis (Fig. 11A-C). The number and distribution of antigens by apparent molecular mass and isoelectric point detected for 


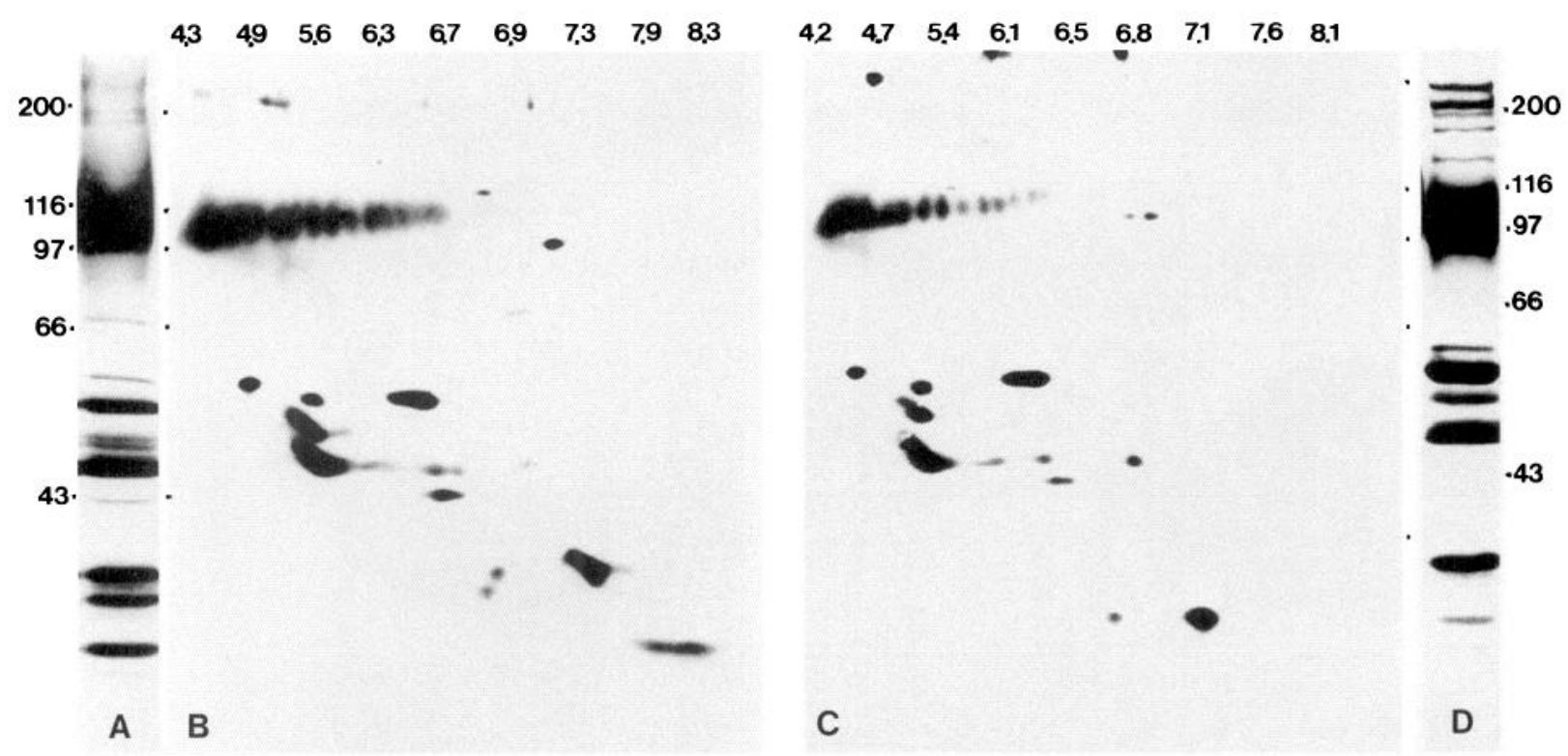

Figure 6. Immunoblot analyses of cerebellar $(A$ and $B)$ and cortical $(C$ and $D)$ type 1 astroglial cell membrane polypeptides, resolved by one- $(A$ and $D$ ) and two-dimensional $\left(B\right.$ and $C$ ) SDS-PAGE, using polyclonal D4 antiserum. pH values are indicated horizontally; molecular mass $\times 10^{-3}$, vertically.

cerebellum was similar to that obtained for cerebral cortex. Significantly, the microdomain antigens also have a similar time course of expression. The $48 \mathrm{kDa}$ antigens (set $\mathrm{A}$ ) are absent in adult cerebellar tissue (Fig. 11A), present at a reduced level toward the end of granule cell migration (Fig. 11B), and are expressed prominently at the initial period of granule cell migration (Fig. $11 \mathrm{C}$ ). In contrast, the $72 \mathrm{kDa}$ antigens (set C) are detected at all stages of cerebellar development analyzed.

Comparative examination of the immunoblots prepared from membrane fractions obtained from isolated cerebellar granule neurons, isolated hippocampal neurons, undifferentiated pheochromocytoma cell line PC-12, and rat glioma cell line C6 revealed antigen profiles that were analogous to the profiles observed in immunoblots of cerebral cortical and cerebellar tissues (data not shown). Thus, none of the microdomain antigens detected in cortical and cerebellar tissues in vivo are expressed selectively by astroglial cells. These immunoblot analyses are consistent with the indirect immunofluorescence analyses carried out on nonpermeabilized astroglial and neuronal cells as well as the detection of microdomains on both the neuronal and the astroglial cell surface in migrating neuronal cell preparations (Fig. 5B).

The $48 \mathrm{kDa}, 72 \mathrm{kDa}$, and 100-120 kDa microdomain antigens are resistant to alkaline extraction treatment utilized in the preparation of membrane fractions, and therefore may be considered preliminarily as integral membrane proteins. Further, the microdomain antigens are solubilized by nonionic detergent treatments only at determent : protein $(\mathrm{w} / \mathrm{w})$ ratios greater than 1.25 , and none of the antigens are recovered in the soluble phase following treatment of isolated membrane fractions or astroglial cells with bacterial phosphatidylinositol-specific phospholipase C. Thus, none of the antigens are likely to be anchored to the plasma membrane by a glycosyl-phosphatidylinositol moiety. Finally, as determined by immunoblot analysis, the microdomain antigens are not components of several cell-soluble fractions examined (see Materials and Methods) (data not shown).

\section{Association of microdomain polypeptides with the membrane cytoskeleton}

The maintenance of plasmalemmal domains requires a mechanism to prevent randomization of associated component polypeptides by lateral diffusion. Since the surface microdomains do not appear to be confined exclusively to regions of cell-cell contact in isolated astroglial cells, the most likely means of restriction in lateral mobility in nonpolarized cells is through an association with selective components of the cytoskeleton. Accordingly, to assess the possibility that microdomain polypeptides interact, directly or indirectly, with components of the cytoskeleton, a detergent-resistant membrane/cytoskeleton fraction of cortical astroglial cells was obtained as described by Ranscht (1988). Electron microscopic analysis demonstrated that the isolated fraction was composed largely of arrays of filamentous material in association with small membrane sheets and vesicles (data not shown). Fractionation of the polypeptide components by two-dimensional SDS-PAGE and subsequent identification by immunoblotting indicated that the D4 antiserum recognized, for the most part, only the antigens considered to contribute to the formation of the microdomains, namely, the $48 \mathrm{kDa}$ polypeptides (antigen set A) and the 100-120 $\mathrm{kDa}$ antigen (Fig. 12).

\section{Effect of cytoskeleton-disrupting drugs on microdomain distribution}

To determine which components of the underlying cytoskeleton could be correlated to maintaining the integrity of microdomain structure, we evaluated the degree to which microdomain structure was maintained following disruption of selective cytoskeletal components.

The role of microtubules in the maintenance of the microdomains was determined by temperature and drug-induced depolymerization of microtubules. The spatial distribution of the microtubule cytoskeleton in primary cultures of cortical astrog- 


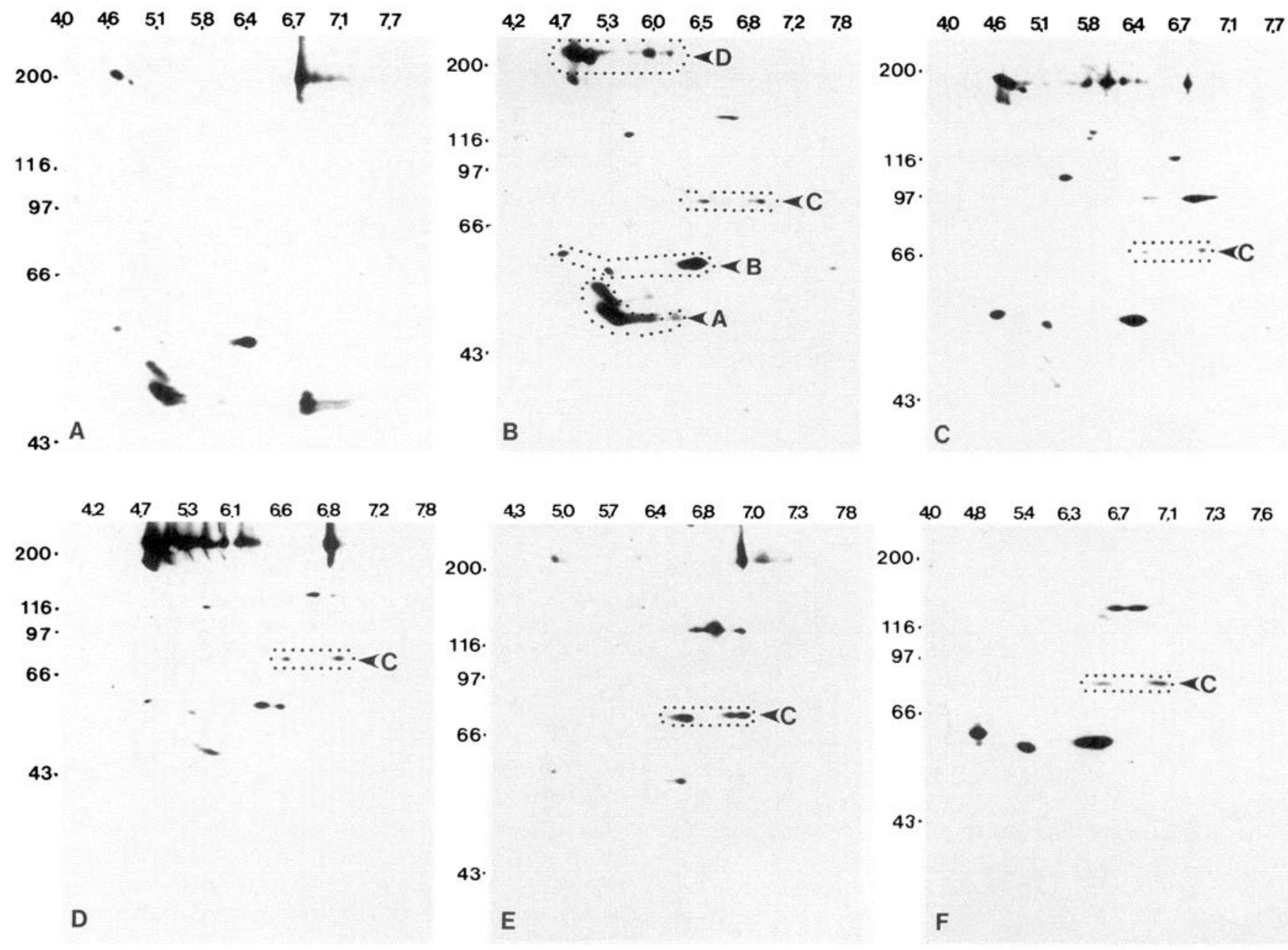

Figure 7. Comparative immunoblot analysis of cerebral cortical membrane polypeptides during development. Membrane preparations were obtained from cerebral cortices at embryonic day $12(A)$, embryonic day $18(B)$, birth $(C)$, neonatal day $12(D)$, and adult $(E)$. Polypeptides were resolved by two-dimensional SDS-PAGE and processed for immunoblot analysis using polyclonal D4 antiserum. As a non-neuronal tissue control, a membrane preparation was obtained from adult liver and polypeptides processed for analogous immunoblot analysis $(F)$. For reference, the four sets of antigens, detailed in the Results, are labeled $A-D$ in panel $B$, and the antigen set $C$ is indicated for all panels. pH values are indicated horizontally; molecular mass $\times 10^{-3}$, vertically.
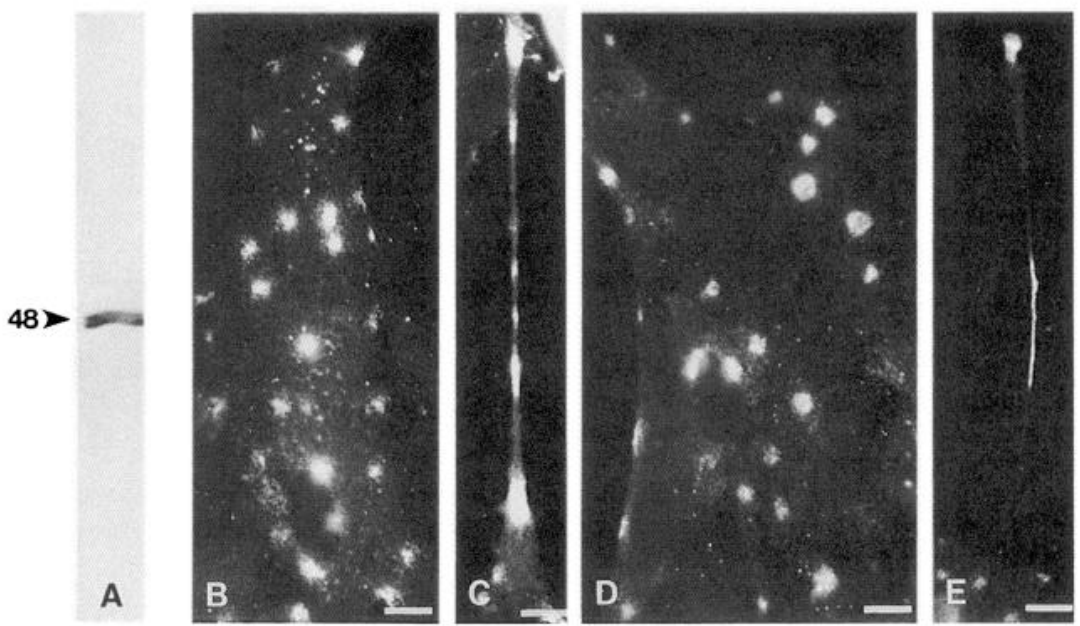

Figure 8. Identification of membrane polypeptides that contribute to the formation of astroglial cell surface microdomains. Cortical glial cell and liver membrane polypeptides were resolved by preparative SDS-PAGE, electrophoretically transferred to nitrocellulose, and incubated with D4 antiserum. Bound antibodies, located by use of a template, were desorbed, concentrated, and used for further immunocytochemical and immunoblot analyses. Affinity-purified antibodies to an astroglial cell $48 \mathrm{kDa}$ polypeptide doublet $(A)$ detect, by indirect immunofluorescence, surface microdomains on both cortical type 1 astroglial $(B)$ and radial glial $(C)$ cells. Affinity-purified antibodies to a $72 \mathrm{kDa}$ polypeptide doublet, present in brain and liver tissues, immunolabels surface microdomains on both type 1 astroglial $(D)$ and radial glial cells $(E)$. Scale bars: $B, 11 \mu \mathrm{m} ; C, 13 \mu \mathrm{m}$; $D, 10 \mu \mathrm{m} ; E, 14 \mu \mathrm{m}$. 

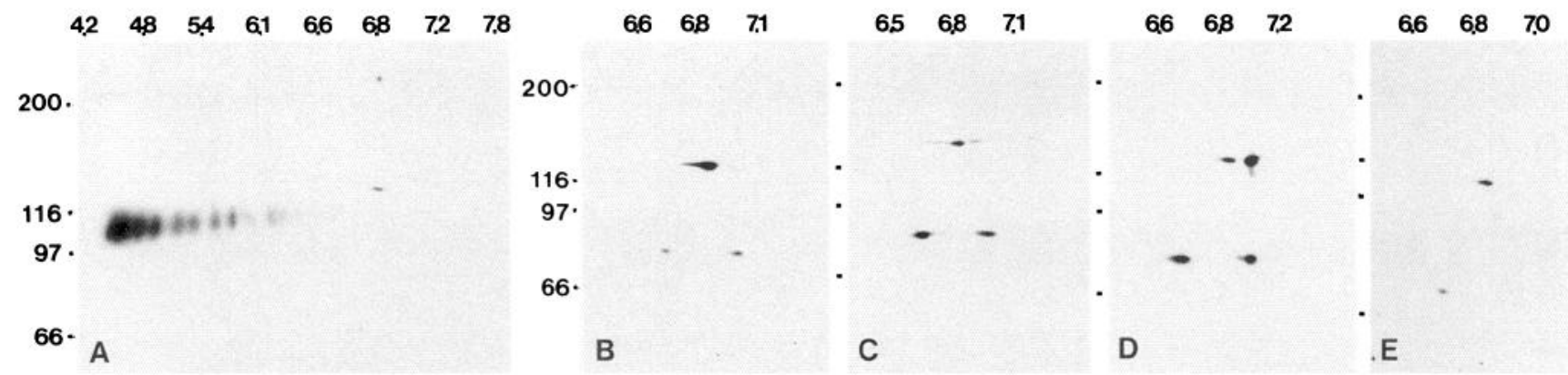

Figure 9. Affinity-purified antibodies to the 100-120 kDa glial cell antigen detect lower-molecular-weight polypeptides in nonastroglial culture cells and in liver and brain tissues. Affinity-purified antibodies to the 100-120 kDa polypeptide, obtained by desorbtion from nitrocellulose immunoblots of cortical astroglial cell polypeptides, were used to probe immunoblots of membrane polypeptide preparations, resolved by twodimensional SDS-PAGE, obtained from cortical astroglial cells $(A)$, PC-12 cells $(B)$, glioma C6 cells $(C)$, and neonatal day 15 cerebellum $(D)$. In cortical astroglial cells, the affinity-purified antibodies detect, primarily, a single polypeptide species that displays multiple isoforms of $100-120$ $\mathrm{kDa}$ and a minor $130 \mathrm{kDa}$ polypeptide. In tissues or cells that do not express the $100-120 \mathrm{kDa}$ polypeptide $(B-D)$, affinity-purified antibodies detect three polypeptides of $\sim 72 \mathrm{kDa}, \sim 72 \mathrm{kDa}$, and $130 \mathrm{kDa}$. Affinity-purified antibodies directed against the $\sim 72 \mathrm{kDa}$ polypeptides, obtained by desorbtion from immunoblots of adult liver membrane polypeptides, when used to probe immunoblots of cortical astroglial membrane preparations resolved by two-dimensional SDS-PAGE, detect the $\sim 72 \mathrm{kDa}$ polypeptides (the more basic polypeptide is detected at reduced levels in comparison to the acidic $\sim 72 \mathrm{kDa}$ polypeptide) and the $130 \mathrm{kDa}$ polypeptide $(E)$. $\mathrm{pH}$ values are indicated horizontally; molecular mass $\times 10^{-3}$, vertically.

lial cells was determined by indirect immunofluorescence using antibodies to $\beta$-tubulin (Fig. 13A). As indicated by the substantial reduction in the polymeric organization of microtubules, nocodazole treatment of cortical glial cells produced a near complete depolymerization of the microtubule network (Fig. 13B). A small but stable microtubule subpopulation in astroglial cells has been noted previously, and reflects the presence of a posttranslational modified form of $\alpha$-tubulin (Cambray-Deakin et al., 1988). Perturbation of the microtubule network with either nocodazole or low temperature treatment resulted in an appar- ent redistribution of D4 immunoreactivity (Fig. 13C-E). Subsequent to nocodazole treatment, immunoreactivity accumulated at the centrosomal region of the cell, with vast expanses of the astroglial cell plasma membrane being devoid of detectable immunoreactivity. This redistribution of D4 immunoreactivity occurred independent of the changes in cell shape, polygonal to process bearing, that accompanied nocodazole treatment in some cells (Fig. $13 C, D$ ). Additionally, in many cases, D4 immunoreactivity appeared to be entirely absent from the cell. Although less effective, D4 immunoreactivity was also

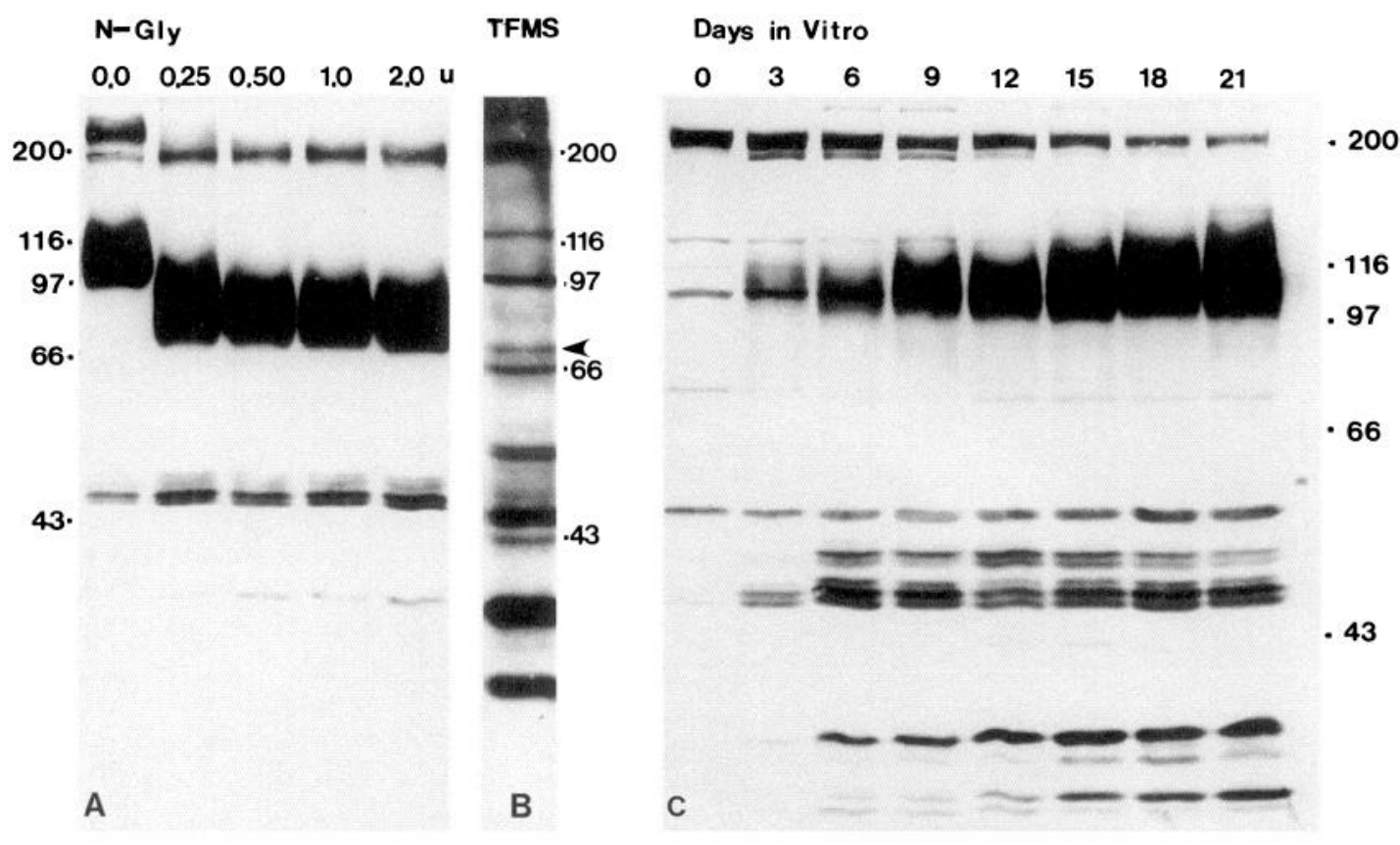

Figure 10. Characterization of the 100-120 kDa antigen. $A$ and $B$, Deglycosylation analyses of the $100-120 \mathrm{kDa}$ polypeptide. Cortical astroglial membrane preparations, processed for deglycosylation analyses using $0-2.0 \mathrm{U}$ of $\mathrm{N}$-glycosidase $\mathrm{F}(A)$ and trifluoromethanesulfonic acid (TFMS, $B$ ), were resolved by one-dimensional SDS-PAGE and processed for immunoblot analysis. The arrowhead in $B$ identifies a polypeptide species of $\sim 72 \mathrm{kDa}$ that is detected in immunoblots of cortical astroglial cell membranes only subsequent to chemical deglycosylation. Molecular mass $\times$ $10^{-3}$ is indicated vertically. $C$, Time course of $100-120 \mathrm{kDa}$ antigen expression by cortical type 1 astroglial cells in culture. Cortical type 1 astroglial cells were maintained in culture from 0 to $21 \mathrm{~d}$ in vitro, and membrane polypeptide preparations were obtained at each time point. Equivalent protein concentrations were resolved by one-dimensional SDS-PAGE and processed for immunoblot analysis using polyclonal D4 antiserum. Molecular mass $\times 10^{-3}$ is indicated vertically. 


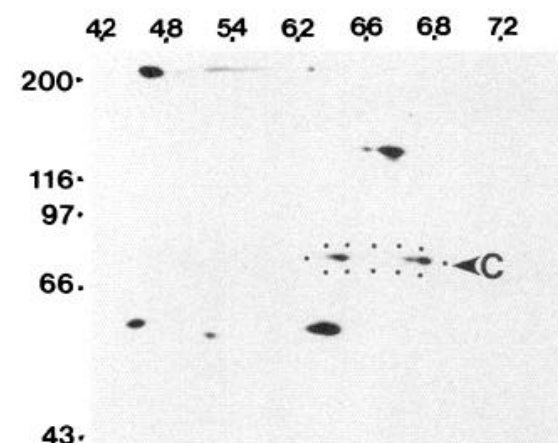

A

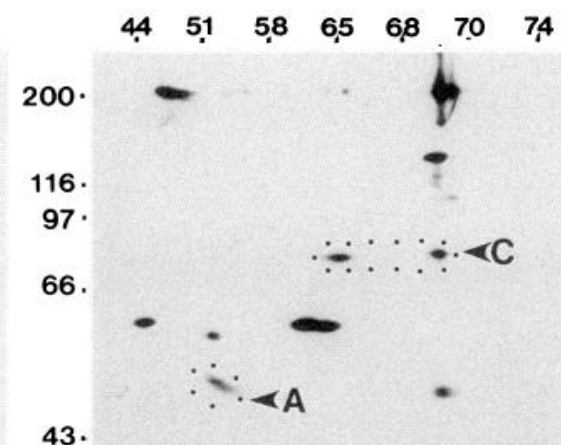

B

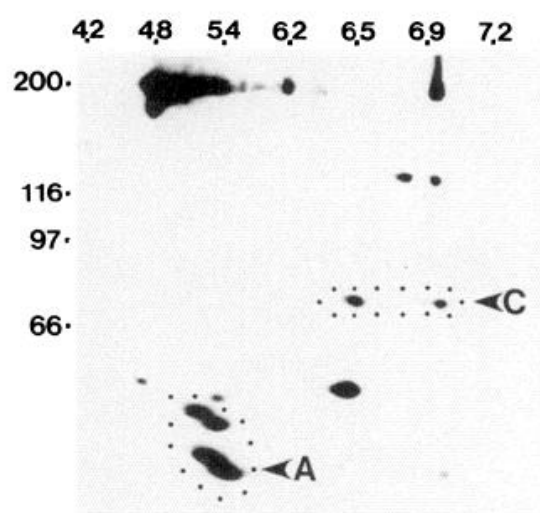

43.

C

Figure 11. Comparative immunoblot analysis of cerebellar membrane polypeptides during development. Membrane fractions were obtained from cerebella at adult $(A)$, neonatal day $15(B)$, and neonatal day $5(C)$. Polypeptides, resolved by two-dimensional SDS-PAGE, were processed for immunoblot analysis using polyclonal D4 antiserum. Antigen sets $A$ and $C$ are outlined for all panels. pH values are indicated horizontally; molecular mass $\times 10^{-3}$, vertically.

redistributed following temperature-induced depolymerization of microtubules (Fig. 13E). Washout of nocodazole, or reincubation of $4^{\circ} \mathrm{C}$ treated cell cultures at $37^{\circ} \mathrm{C}$, did not result in the reformation of cell surface microdomains, at least on the time scale examined ( 60 min, data not shown). Lastly, we evaluated the extent to which the maintenance of the surface microdomains was effected by extracellular calcium concentration. To this end, primary cell cultures of cortical astrocytes were incubated in EGTA/EDTA supplemented $\mathrm{Ca}^{2+} / \mathrm{Mg}^{2+}$-free medium and subsequently processed for indirect immunofluorescent analysis. Evidently, the integrity of the surface microdomains is maintained in the absence of extracellular $\mathrm{Ca}$ and $\mathrm{Mg}$ ions (Fig. 13F).

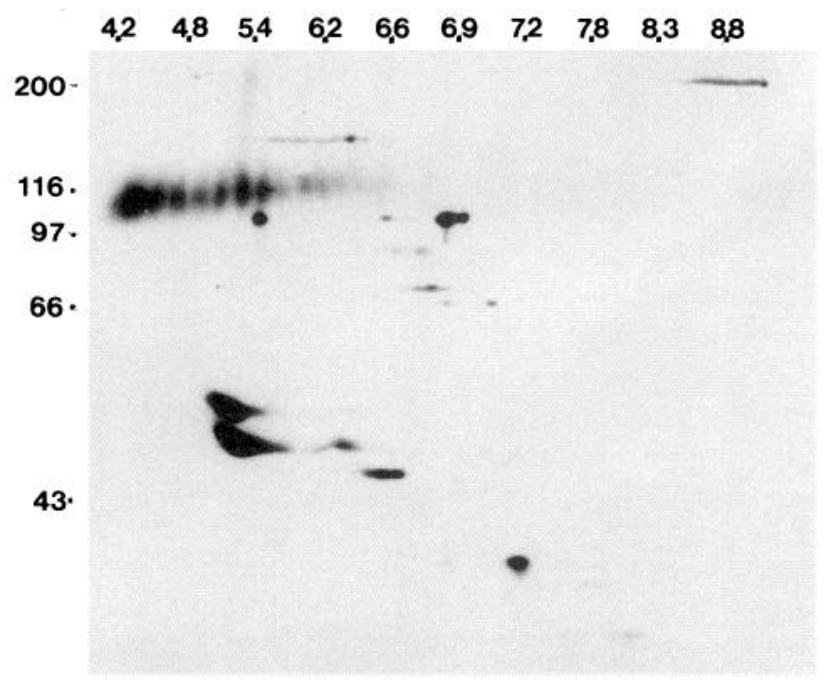

Figure 12. Immunoblot analysis of membrane/cytoskeleton fraction isolated from cortical astroglial cells by discontinuous density gradient centrifugation. Isolated membrane/cytoskeletal fractions were resolved by two-dimensional SDS-PAGE, and processed for immunoblot analysis using the polyclonal D4 antiserum. The 100-120 kDa and the 48/ $52 \mathrm{kDa}$ polypeptides, which contribute to the formation of the microdomains, are the predominant polypeptide species detected. $\mathrm{pH}$ values are indicated horizontally; molecular mass $\times 10^{-3}$, vertically.
In order to determine the distribution of actin and actinassociated focal adhesion plaques, isolated astroglial cells were labeled with rhodamine-phalloidin and examined by fluorescence microscopy. In no case have we observed a spatial correlation between the surface microdomains and filamentous actin or actin-membrane attachment sites (Fig. 14A,B). Additionally, we examined, by indirect immunofluorescence, the distribution of vinculin, a prominent component of the membrane termini of F-actin bundles that participate in the formation of cell-cell and cell-substratum adhesions (Otto, 1990; Geiger and Ginsberg, 1991). As anticipated, we did not observe a colocalization of vinculin with cell surface microdomains (data not shown; see Abd-El-Basset et al., 1991). Taken together, these data suggested that the integrity of the surface microdomains may not require the presence of the actin cytoskeleton. To assess more clearly this possibility, we carried out analyses using cytochalasin B or D treatments, which disrupt the actin filament network organization (Schliwa, 1982). In the presence of cytochalasin B or D, epithelial-like astrocytes transform morphologically into a population of process-bearing astrocytes. Process formation appears to be accompanied by an extensive rearrangement of actin filaments; rhodamine-phalloidin is detected, to a large extent, at the tips of the processes or as filamentous aggregates or small foci scattered along the plasmalemmal surface (data not shown; see Baorto et al., 1992). Nonetheless, astroglial cells treated with cytochalasin B or D displayed typical cell surface microdomains (Fig. 14C). However, in addition, immunoreactivity was also observed on the plasmalemmal surface as circular structures. These structures have an average surface area of $0.9 \mu \mathrm{m}^{2}\left(\mathrm{~min}, 0.04 \mu \mathrm{m}^{2} ; \max , 6.5 \mu \mathrm{m}^{2} ; \mathrm{SD}, 0.9\right)$ (Fig. 14D). In many instances, detail observation of the surface microdomains revealed an underlying circular substructure, although further analyses will be required to determine a possible relationship between the circular structures and the surface microdomains (Fig. 14E). Lastly, we determined the distribution of the $\alpha 1$ and $\beta 1$ integrins. The integrins comprise a complex family of $\alpha \beta$-heterodimeric adhesion polypeptides that function, in large part, as receptors for extracellular matrix components and are known to associate with actin (Hynes, 1992). Immu- 

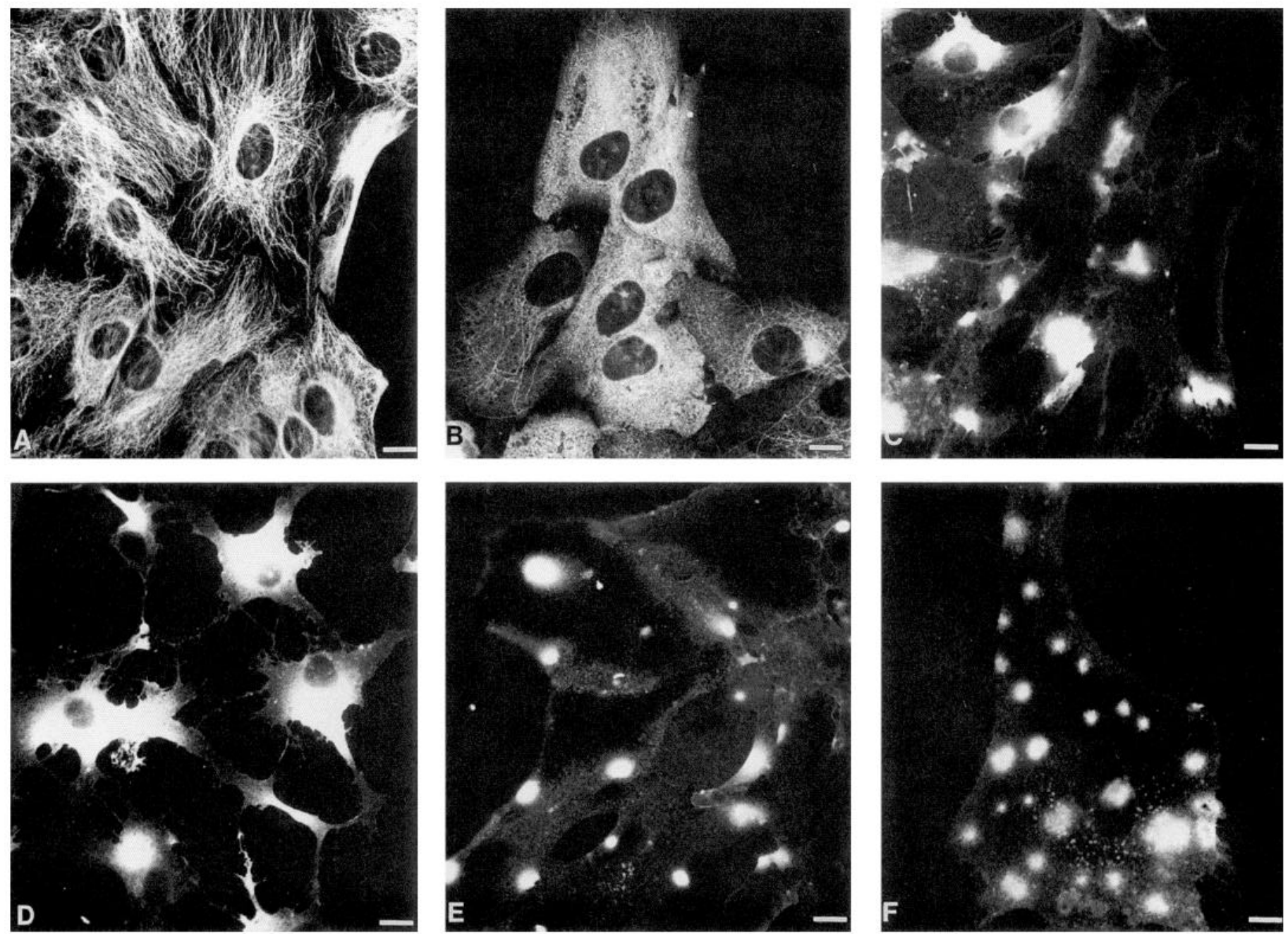

Figure 13. Distribution of cell surface microdomains following treatments that disrupt the association between transmembrane proteins and the microtubule cytoskeleton. $A-C$, Fluorescence micrographs illustrating the distribution of $\beta$-tubulin immunoreactivity in control and nocodazoletreated cortical astroglial cells. In nontreated astroglial cells, fibrillar arrays of microtubules radiate from the centrosomal region and extend throughout the cell $(A)$. After nocodazole treatment, most microtubules are depolymerized as assessed by the diffuse immunofluorescent pattern observed for $\beta$-tubulin $(B) . C-E$, Fluorescence micrographs illustrating the distribution of microdomain antigens in nonpermeabilized astroglial cells following nocodazole and low temperature treatment. In nocodazole-treated cells, D4 immunoreactivity is redistributed from surface patches to large fluorescent aggregates at microtubule organizing centers in cells that continue to maintain an epithelial-like cell shape $(C)$, as well as in cells that appear to be undergoing a change in cell shape $(D)$. The extent of redistribution of microdomain antigens is less in cells subjected to low-temperature $\left(4^{\circ} \mathrm{C}\right)$ treatment $(E)$, although, even in these cells, large expanses of surface membrane are devoid of detectable D4 immunoreactivity. $F$, Distribution of D4 immunoreactivity as revealed by indirect immunofluorescence in nonpermeabilized cortical glial cells following incubation in calcium/magnesium-free medium supplemented with EGTA and EDTA. The distribution of microdomains, both in number and in size, appears to be unaffected by the withdrawal of extracellular calcium and magnesium $(F)$. Scale bars: $A, 12 \mu \mathrm{m} ; B$ and $D, 11 \mu \mathrm{m} ; C$ and $F, 10 \mu \mathrm{m} ; E, 13 \mu \mathrm{m}$.

nostaining of type 1 astrocytes and radial glial cells with antibodies specific for the $\alpha 1$ and $\beta 1$ integrin subunits revealed a uniform distribution of fluorescent puncta over the plasma membrane (Fig. 14F, $G$ ). Thus, the D4-positive microdomains are unlikely to represent adhesion receptor sites for interaction with extracellular matrix components.

\section{Discussion}

Antigens that contribute to the formation of junctional microdomains

Indirect immunofluorescent analyses carried out using the heterologous polyclonal antiserum D4 revealed that the antigens recognized in nonpermeabilized type 1 astroglial cells and radial glial cells were concentrated in multiple cell surface patches or microdomains. In type 1 astroglial cells, these surface microdomains were associated with the free cell surface, although microdomains were aligned less frequently in register at sites of astroglial-astroglial cell contact. In preparations containing cells with the morphology of migrating neuronal cells, a single prominent microdomain was localized to the site where the neuronal cell soma was in contact with the surface of an elongated glial cell. Smaller microdomain foci were also observed along the glial cell process in advance of the neuronal cell soma. The localization of D4 immunoreactivity in these cell preparations resembles the specialized membrane-membrane appositions that are usually associated with migrating neuronal cells: the interstitial junction and the puncta adherens (Rakic, 1972; Gregory et al., 1988; Hatten, 1990). Additional immunocytochemical analyses at the electron microscopic level are necessary to verify 

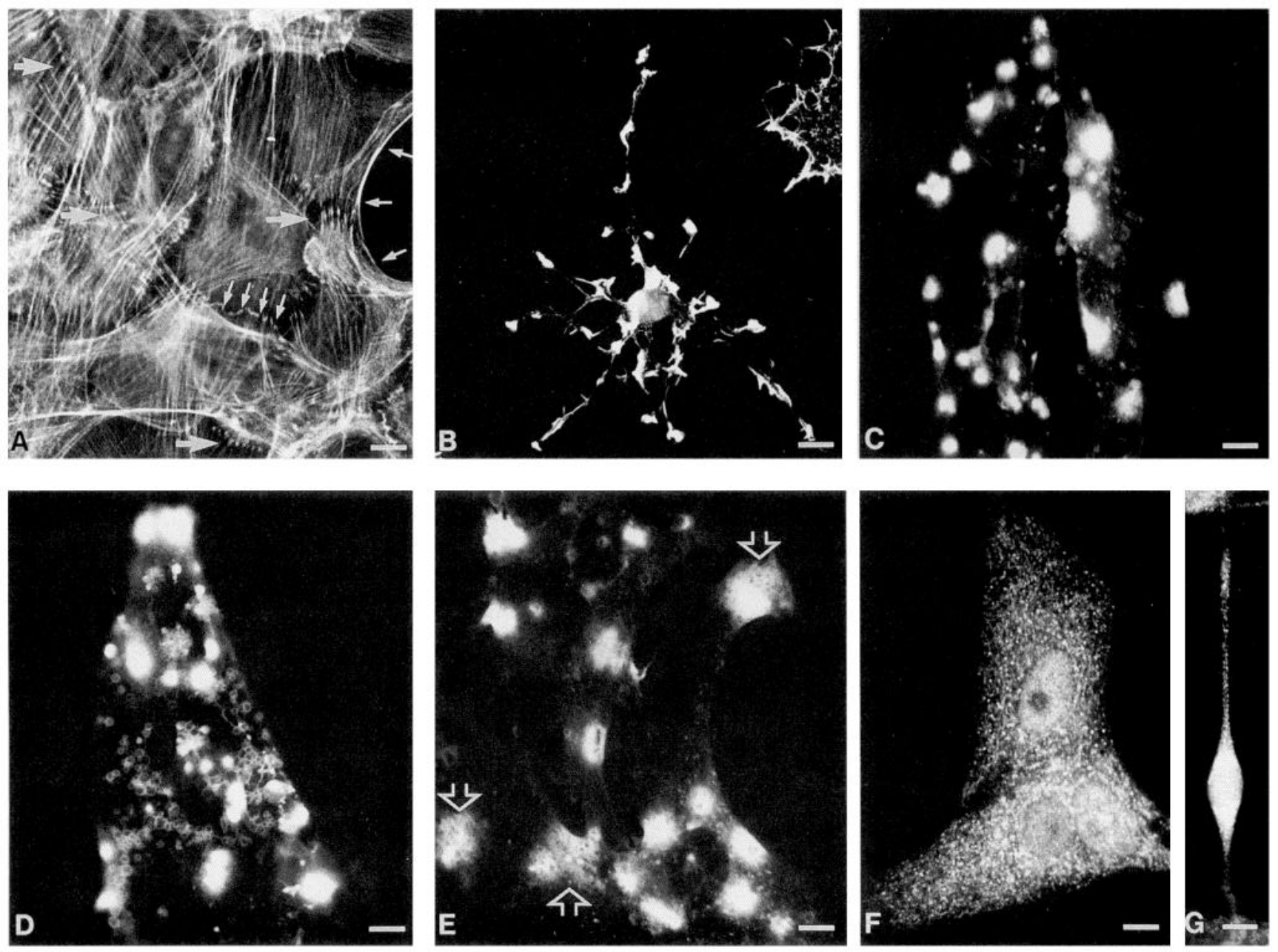

Figure 14. Distribution of cell surface microdomains following treatments that disrupt the association between transmembrane proteins and the actin cytoskeleton. $A$ and $B$. Fluorescence micrographs illustrating the distribution of rhodamine-phalloidin in cortical type 1 and process-bearing astroglial cells. In type 1 astroglial cells, arrays of filamentous actin radiate throughout the cell $(A)$. Actin-membrane attachment sites are detected throughout the cell as small fluorescent puncta (large arrows in $A$ ), while continuous bands of F-actin are associated with cell and cell-cell borders (small arrows in A). In process-bearing astrocytes, phalloidin is detected as large aggregates at the tips and along the length of the astroglial cell processes. $C-E$, Fluorescence micrographs illustrating the distribution of microdomain antigens in cortical astroglial cells following incubation in cytochalasin B, which disrupts the actin cytoskeleton. Although dramatic changes in cell shape accompany the disruption of the actin network, prominent microdomain structures are still observed $(C)$. However, cytochalasin treatment of astroglial cells leads to the appearance of many small circular images $(D)$, which appear to comprise a substructure that underlies the microdomains (arrows in $E$ ). $F$ and $G$, Fluorescence micrographs illustrating the distribution of $\alpha 1$-integrin immunoreactivity in cortical type 1 astroglial cells and radial glial cells. Immunoreactivity is detected in type 1 astrocytes $(F)$ and radial glial cells $(G)$ as small fluorescent puncta scattered throughout the cell. Scale bars: $A$ and $G, 10 \mu \mathrm{m} ; B, 13 \mu \mathrm{m} ; C$, $9 \mu \mathrm{m} ; D-F, 8 \mu \mathrm{m}$.

correspondence between these junctions and the microdomains of D4 immunoreactivity.

Among the spectrum of antigens recognized by the polyclonal antiserum, only the polypeptides of apparent molecular mass $\sim 48 \mathrm{kDa}$ and $\sim 72 \mathrm{kDa}$ contribute to the formation of the surface microdomains. The $48 \mathrm{kDa}$ antigen is expressed in both astroglial and neuronal cells and has not been detected in nonneural epithelial tissues. It is detected in a given neural structure only at developmental periods that coincide with active neuronal cell migration. In contrast, the $72 \mathrm{kDa}$ antigen is expressed in all tissues examined and is detected initially at late developmental stages. The contribution of the 100-120 kDa antigen, whose expression is limited to type 1 astroglial cells in culture, to the formation of surface microdomains is suggestive but not conclusive. Although present data are consistent with the possibility that the $100-120 \mathrm{kDa}$ antigen represents an extensively glycosylated form of the $72 \mathrm{kDa}$ antigen, we have been unable to evaluate this suggestion directly. Thus, definitive proof of the identity of the 100-120 kDa polypeptide awaits the development of monospecific antiserum.

\section{Involvement of microdomain antigens in cell migration events}

Although the function(s) of the antigens that comprise the surface microdomains is unknown, the site and pattern of their distribution, as well as the timing of their appearance, suggest that they may be involved in neuronal cell migration events. To date, analyses carried out on astrocytes grown on microporous filters have not detected D4-positive microdomains at the plasmalemmal-substratum interface. This observation is consistent with immunolocalization analyses that show that $\alpha 1$ and $\beta 1$ integrin subunits do not colocalize to the D4-positive microdomains (Tawil et al., 1990, 1993; Tawil and Carbonetto, 
1991). Previous analyses of neuronal cell migration have established several criteria relevant to the interpretation of the possible function(s) carried out by the microdomain antigens, including selective cell recognition, cell adhesion, and cell translocation.

In vitro analyses have demonstrated that neuronal cell movement along radial glial cell processes involves the formation of a specialized junctional complex (Gregory et al., 1988; Gasser and Hatten, 1990a,b; Fishell and Hatten, 1991). Significantly, astrotactin, a prominent component of the molecular machinery implicated in mediating neuronal cell translocation during cell migration, is concentrated at the level of the interstitial junction (Fishell and Hatten, 1991). The localization of the $48 \mathrm{kDa}, 72$ $\mathrm{kDa}$, and 100-120 kDa microdomain antigens in a similar pattern and the absence of microdomains in process-bearing astrocytes and oligodendrocytes are consistent with a role for the microdomain antigens in cell translocation events. Further, the microtubule cytoskeleton has been suggested preliminarily to be the principal cytoskeletal component underlying neuronal cell movement along elongated glial cell fibers (Rivas et al., 1991). Therefore, it may be significant that a loss of individual cell surface microdomains in our experiments occurs as a consequence of treatment of astroglial cell cultures with drugs that perturb the microtubule, but not the actin, cytoskeleton. Detection of only microdomain antigens in isolated membrane/ cytoskeleton fractions provides additional indirect evidence of an association with cytoskeletal components.

Lastly, the presence of multiple, free microdomains on the surface of type 1 astrocytes ( $\sim 95 \%$ of total) and radial glial cells is consistent with a possible primary role in neuronal cell movement. Evidently, the presence of neuronal cell contact is not a prerequisite for microdomain formation by astroglial cells. As shown for several other cell adhesion assemblies, once formed, microdomains are quite stable, either through an association with components of the underlying cytoskeleton or through an association with receptor ligands (Mege et al., 1988; Albelda et al., 1990; Matsuzaki et al., 1990; Bloch, 1992). In contrast, microdomain formation by neuronal cells appears to require not only neuronal cell-glial cell contact but also that the neuron be in the process of migration. Nonmigrating neurons adhered to elongated glial cell processes display a uniform, nonpolarized distribution of D4 immunoreactivity. If the uniform immunofluorescence observed for nonmigrating, adhered neurons and the highly polarized distribution observed for cells with the morphology of migrating neurons represent the extreme possible localization of microdomain polypeptides, then images of incomplete localization may reflect intermediate stages in microdomain development. However, we emphasize that we have no knowledge pertaining to the biosynthetic mechanism of microdomain assembly by neuronal cells: selective insertion of newly synthesized components and/or the clustering of the randomly distributed microdomain polypeptides to a single plasmalemmal domain as a consequence of glial cell interaction. Alternatively, at present, we cannot exclude the possibility that the formation of interacting microdomains is achieved by a mechanism similar to agrin-mediated $\mathrm{ACh}$ receptor clustering on myotubes (Ferns et al., 1992; Ruegg et al., 1992).

In contrast to participation in cell movement, microdomain antigens could function in a strictly adhesive capacity analogous to the function carried out by components of junctional complexes present in various non-neural epithelial (Farquhar and Palade, 1963). Considerable evidence suggests that astroglial cells express and assemble classical junctional components into specialized adhesion plaques. Gap junction components have a cell surface distribution in astroglial cells that resembles the distribution of the D4-positive microdomains identified in this report (Dermietzel et al., 1991). The tight junction-associated protein ZO-1 (Stevenson et al., 1988) has been localized, in part, to sites of cell-cell contact in primary cell cultures of cortical astrocytes and in cultures of $\mathrm{C} 6$ glioma cells (Horwarth ct al., 1990). Additionally, the hemidesmosomal component HDI (Hieda et al., 1992), but not the desmosomal component plakoglobin (Cowin et al., 1986), has been detected in astroglial cells. However, if D4-positive microdomain antigens function in an analogous cell adhesion capacity, they form a distinct subset of cell adhesion receptors, since, with few exceptions (Wacker et al., 1992), interaction with the actin cytoskeleton, rather than the microtubule cytoskeleton, is critical for receptors implicated in cell adhesion functions, for example, cadherin (Nagafuchi and Takeichi, 1988; Ozawa et al., 1989, 1990; Nagafuchi et al., 1991; Hirano et al., 1992; Kinter, 1992), $\beta 1$-integrin (Hynes, 1992), and N-CAM 180 (Pollerberg et al., 1986, 1987). Indeed, cell-cell adhesive interactions mediated by these receptor systems are inhibited by treatments that disrupt the actin cytoskeleton (Horowitz et al., 1986; Matsuzaki et al., 1990; Otey et al., 1990).

In conclusion, the phenomenon of neuronal cell migration appears to be multifaceted and more complex than initially envisaged. Antibodies that perturb cell adhesion/aggregation events have been used extensively to identify a large repertoire of proteins that participate in adhesive interactions in the developing CNS. Interruption of the adhesion function for all identified adhesion polypeptides curtails neuronal cell migration in a variety of assay systems, although differing experimental paradigms have yielded contrasting results in several instances (Galileo et al., 1992; Saga et al., 1992). Thus, proper neuronal migration may rely on a combinatorial and possibly sequential use of these multiple adhesion components. However, adhesion receptors that subserve specific cellular functions have not been identified. We have identified two membrane polypeptides that contribute to the junction between cells with the morphology of migrating neurons and radial glial cells, and suggest that these polypeptides participate at a defined stage in cell migration. However, a test of this hypothesis has to await the further development of monospecific polyclonal and monoclonal antibodies and their usage in various cell adhesion and cell migration assays.

\section{References}

Abd-El-Basset EM, Ahmed I, Fedoroff S (1991) Actin and actin-binding proteins in differentiating astroglia in tissue culture. $\mathrm{J}$ Neurosci Res 30:1-17.

Albelda SM, Oliver PD, Romer LH, Buck CA (1990) EndoCAM: a novel endothelial cell-cell adhesion molecule. J Cell Biol 110:12271237.

Andrews NC, Faller DV (1991) A rapid micropreparation technique for extraction of DNA-binding protcins from limiting numbers of mammalian cells. Nucleic Acids Res 19:2499.

Antonicek H, Persohn E, Schachner M (1987) Biochemical and functional characterization of a novel neuron-glia adhesion molecule that is involved in neuronal migration. J Cell Biol 104:1587-1595.

Banker GA, Cowan WM (1977) Rat hippocampal neurons in dispersed cell culture. Brain Res 126:379-425.

Baorto DM, Mellado W, Shelanski ML (1992) Astrocyte process growth induction by actin breakdown. J Cell Biol 117:357-367.

Bartlett WP, Banker GA (1984) An electron microscopic study of the development of axon and dendrites by hippocampal neurons in cul- 
ture. I. Cells which develop without intracellular contacts. J Neurosci 4:1944-1953.

Bloch RJ (1992) Clusters of neural cell adhesion molecule at sites of cell-cell contact. J Cell Biol 1 16:449-463.

Brady-Kalnay SM, Flint AJ, Tonks NK (1993) Homophilic binding of $\mathrm{PTP} \mu$, a receptor type protein tyrosine phosphatase, can mediate cell-cell aggregation. J Cell Biol 122:961-972.

Cambray-Deakin MA, Robson SJ, Burgoyne RD (1988) Colocalization of acetylated microtubules, glial filaments and mitochondria in astrocytes in vitro. Cell Motil Cytoskel 10:438-449.

Cameron PL, Sudhof TC, Jahn R, DeCamilli P (1991) Co-localization of synaptophysin with transferrin receptors: implications for synaptic vesicle biogenesis. J Cell Biol 115:151-164.

Cameron RS, Rakic P (1991) Glial cell lineage in the cerebral cortex: a review and synthesis. Glia 4:124-137.

Cameron RS, Cameron PL, Castle JD (1986) A common spectrum of polypeptides occurs in secretion granule membranes of different exocrine glands. J Cell Biol 103:1299-1313.

Cowin P, Kapprell H-P, Franke WW, Tamkun J, Hynes RO (1986) Plakoglobin: a protein common to different kinds of intercellular adhering junctions. Cell 46:1063-1073.

Culican SM, Baumrind NL, Yamamoto M, Pearlman AL (1990) Cortical radial glia: identification in tissue culture and evidence for their transformation to astrocytes. J Neurosci 10:684-692.

Davis LI, Blobel G (1986) Identification and characterization of a nuclear pore complex. Cell 45:699-709.

DeCamilli P, Cameron R, Greengard P (1983) Synapsin 1 (Protein 1), a nerve terminal-specific phosphoprotein. I. Its general distribution in synapses of the central and peripheral nervous system demonstrated by immunofluorescence in frozen and plastic sections. J Cell Biol 96:1337-1354.

Dermietzel R, Hertzberg EL, Kessler JA, Spray DC (1991) Gap junctions between cultured astrocytes: immunocytochemical, molecular, and electrophysiological analysis. J Neurosci 11:1421-1432.

Eckenhoff MF, Rakic P (1984) Radial organization of the hippocampal dentate gyrus: a Golgi, ultrastructural and immunohistochemical analysis in the developing thesus monkey. J Comp Neurol 223:1-21.

Edelman GM, Crossin KL (1991) Cell adhesion molecules: implications for a molecular histology. Annu Rev Biochem 60:155-190.

Edmondson JC, Hatten ME (1987) Glial-guided granule neuron migration in vitro: a high-resolution time-lapse video microscopic study. J Neurosci 7:1928-1934.

Edwards MA, Yamamoto M, Caviness VS Jr (1990) Organization of radial glial and related cells in the developing murine CNS: an analysis based upon a new monoclonal antibody marker. Neuroscience 36 : $121-144$.

Farquhar MG, Palade GE (1963) Junctional complexes in various epithelia. J Cell Biol 17:375-412.

Ferns M, Hoch W, Campanelli JT, Rupp F, Hall ZW, Scheller RH (1992) RNA splicing regulates agrin-mediated acetylcholine receptor clustering activity on cultured myotubes. Neuron 8:1079-1086.

Fishell G, Hatten ME (1991) Astrotactin provides a receptor system for CNS neuronal migration. Development 113:755-765.

Freidman B, Hockfield S, Black JA, Woodruff KA, Waxman SG (1989) In situ demonstration of mature oligodendrocytes and their processes: an immunocytochemical study with a new monoclonal antibody, RIP. Glia 2:380-390.

Friedlander DR, Mege R-M, Cunningham BA, Edelman GM (1989) Cell sorting-out is modulated by both the specificity and amount of different cell adhesion molecules (CAMS) expressed on cell surfaces. Proc Natl Acad Sci USA 86:7043-7047.

Fujiki Y, Hubbard AL, Fowler S, Lazarow PB (1982) Isolation of intracellular membranes by means of sodium carbonate treatment: applications to endoplasmic reticulum. J Cell Biol 93:97-102.

Galileo DS, Majors J, Horwitz AF, Sanes JR (1992) Retrovirally introduced antisense integrin RNA inhibits neuroblast migration in vivo. Neuron 9:1117-1131.

Gard AL, Pfeiffer SE (1989) Oligodendrocyte progenitors isolated directly from developing telencephalon at a specific phenotypic stage: myelinogenic potential in a defined environment. Development 106 : $119-132$.

Gasser UE, Hatten ME (1990a) Neuron-glia interactions of rat hippocampal cells in vitro: glial-guided neuronal migration and neuronal regulation of glial differentiation. J Neurosci 10:1276-1285.

Gasser UE, Hatten ME (1990b) CNS neurons migrate on astroglial fibers from heterotypic brain regions in vitro. Proc Natl Acad Sci USA 87:4543-4547.

Gebbink MFBG, Zondag GCM, Wubbolts RW, Beijersbergen RL, van Etten I, Moolenaar WH (1993) Cell-cell adhesion mediated by a receptor-like tyrosine phosphatase. J Biol Chem 268:16101-16104.

Geiger B, Ginsberg D (1991) The cytoplasmic domain of adherenstype junctions. Cell Motil Cytoskel 20:1-6.

Gloor S, Antonicek H, Sweadner KJ, Pagliusi S, Franck R, Moos M, Schachner M (1990) The adhesion molecule on glia (AMOG) is a homologue of the $\beta$ subunit of the $\mathrm{Na}, \mathrm{K}-\mathrm{ATPase}$. J Cell Biol 110 : $165-174$.

Greene LA, Tischler AS (1976) Establishment of a noradrenergic clonal line of rat adrenal pheochromocytoma cells which respond to nerve growth factor. Proc Natl Acad Sci USA 73:2424-2428.

Gregory WA, Edmondson JC, Hatten ME, Mason CA (1988) Cytology and neuron-glial apposition of migrating cerebellar granule cells in vitro. J Neurosci 8:1728-1738.

Hatten ME (1985) Neuronal regulation of astroglial morphology and proliferation in vitro. J Cell Biol 100:384-396.

Hatten ME (1987) Neuronal inhibition of astroglial cell proliferation is membrane mediated. J Cell Biol 104:1353-1360.

Hatten ME, Mason CA (1990) Mechanisms of glial-guided neuronal migration in vitro and in vivo. Experientia 46:907-916.

Hieda Y, Nishizawa Y, Uematsu J, Owaribe K (1992) Identification of a new hemidesmosomal protein, HDl: a major, high molecular mass component of isolated hemidesmosomes. J Cell Biol 1 16:14971506.

Hirano S, Kimoto N, Shimoyama Y, Hirohashi S, Takeichi M (1992) Identification of a neural $\alpha$-catenin as a key regulator of cadherin function and multicellular organization. Cell 70:293-301.

Hockfield S, McKay RDG (1985) Identification of major classes in the developing mammalian nervous system. J Neurosci 5:3310-3328.

Horowitz A, Duggan K, Buck C, Beckerle MC, Burridge K (1986) Interaction of plasma membrane fibronectin receptor with talin, a transmembrane linkage. Nature 320:531-533.

Horvath E, Edwards AM, Bell JC, Braun PE (1989) Chemical deglycosylation on a micro-scale of membrane glycoproteins with retention of phosphoryl-protein linkages. J Neurosci Res 24:398-401.

Horwarth AG, Hughes MR, Stevenson BR (1990) Detection of the tight junction-associated protein $\mathrm{ZO}-1$ in primary cultures of rat cortical astrocytes. J Cell Biol 111:409a.

Hynes RO (1992) Integrins: versatility, modulation, and signaling in cell adhesion. Cell 69:11-25.

Kinter C (1992) Regulation of embryonic cell adhesion by the cadherin cytoplasmic domain. Cell 69:225-236.

Komuro H, Rakic P (1992) Selective role of $N$-type calcium channels in neuronal migration. Science 257:806-809.

Laemmli UK (1970) Cleavage of structural proteins during the assembly of the head of bacteriophage T4. Nature 227:680-685.

Levison SW, McCarthy KD (1991) Astroglia in culture. In: Culturing nerve cells (Banker G, Goslin K, eds), pp 309-336. Cambridge, MA: Bradford/MIT Press.

Levitt P, Rakic P (1980) Immunoperoxidase localization of glial fibrillary protein in radial glial cells and astrocytes of the developing rhesus monkey brain. J Comp Neurol 193:81 5-840.

Markwell MA, Haas SM, Bieber LL, Tolbert NE (1978 A modification of the Lowry procedure to simplify protein determination in membrane and lipoprotein samples. Anal Biochem 87:206-210.

Matsuzaki F, Mege R-M, Jaffe SH, Friedlander DR, Gallin WJ, Goldbcrg JI, Cunningham BA, Edclman, GM (1990) cDNAs of cell adhesion molecules of different specificity induce changes in cell shape and boarder formation in cultured S180 cells. J Cell Biol 110:12391252 .

Mege R-M, Matsuzaki F, Gallin WJ, Goldberg JI, Cunningham BA, Edelman GM (1988) Construction of epitheloid sheets by transfection of mouse sarcoma cells with cDNAs for chicken cell adhesion molecules. Proc Natl Acad Sci USA 85:7274-7278.

Misson J-P, Austin CP, Takahashi T, Cepko CL, Caviness VS Jr (1991) The alignment of migrating neural cells in relation to neopallial radial glial fiber system. Cereb Cortex 1:221-229.

Nagafuchi A, Takeichi M (1988) Cell binding function of E-cadherin is regulated by the cytoplasmic domain. EMBO J 7:3679-3684.

Nagafuchi A, Takeichi M, Tsukita S (1991) The 102-kd cadherin associatcd protein: similarity to vinculin and posttranscriptional regulation of expression. Cell 65:849-857. 
Nose A, Nagafuchi A, Takeichi M (1988) Expressed recombinant cadherins mediate cell sorting in model systems. Cell 54:993-1001.

Nowakowski RS, Rakic P (1979) Mode of migration of neurons to the hippocampus: a Golgi and electron microscopic analysis in fetal rhesus monkey. J Neurocytol 8:697-718.

Otey CA, Pavelko FM, Burridge K (1990) An interaction between $\alpha$-actinin and the $\beta 1$ integrin subunit in vitro. J Cell Biol 111:721729.

Otto JJ (1990) Vinculin. Cell Motil Cytoskel 16:1-6.

Ozawa M, Baribault M, Kemler R (1989) The cytoplasmic domain of the cell adhesion molecule uvomorulin associates with three independent proteins structurally related in different species. EMBO J 8:1711-1717.

Ozawa M, Ringwald M, Kemmler R (1990) Uvomorulin-catenin complex formation is regulated by a specific domain in the cytoplasmic region of the cell adhesion molecule. Proc Natl Acad Sci USA 87: 4246-4250.

Pollcrberg GE, Schachner M, Davoust J (1986) Differentiation statedependent surface mobility of 2 forms of NCAM. Nature 324:462465.

Pollerberg GE, Burridge K, Krebs K, Goodman S, Schachner M (1987) The $180 \mathrm{kD}$ component of neural cell adhesion molecule is involved in cell-cell contacts and cytoskeleton-membrane interactions. Cell Tissue Res 250:227-238.

Pourquie O, Corbel C, Le Caer J-P, Rossier J, Le Douarin NM (1992) BEN, a surface glycoprotein of the immunoglobulin superfamily, is expressed in a variety of developing systems. Proc Natl Acad Sci USA 89:5261-5265.

Raff MC (1989) Glial cell diversification in the rat optic nerve. Science 243:1450-1455.

Rakic P (1971) Neuron-glia relationships during granule cell migration in devcloping cercbellar cortex. A Golgi and electron microscopic study in Macacus rhesus. J Comp Neurol 141:283-312.

Rakic P (1972) Mode of migration to the superficial layers of fetal monkey neocortex. J Comp Neurol 145:61-84.

Rakic P (1977) Genesis of the dorsal lateral geniculate nucleus in the rhesus monkey: site and time of origin, kinetics of proliferation, routes of migration. J Comp Neurol 176:23-52.

Rakic P (1985) Contact regulation of neuronal migration. In: The cell in contact. Adhesions and junctions as morphogenetic determinants (Edelman GM, Thiery J-P, eds), pp 67-91. New York: Wiley.

Rakic P (1990) Principles of neural cell migration. Experientia 46: 882-891

Ramon y Cajal S (1891) Sur la structure de l'ecorce cerebrale de quelques mammiferes. La Cellule 7:125-178.

Ranscht B (1988) Sequence of contactin, a $130 \mathrm{kD}$ glycoprotein concentrated in areas of interneuronal contact defines a new member of the immunoglobulin supergene family in the nervous system. J Cell Biol 107:1561-1573.

Rao ASMK, Hausman RE (1993) cDNA for R-cognin: homology with a multifunctional protein. Proc Natl Acad Sci USA 90:2950-2954.

Rickmann M, Amaral DG, Cowan WM (1987) Urganization of radial glial cells during the development of the rat dentate gyrus. J Comp Neurol 264:449-479.

Rivas RJ, Fishell G, Hatten ME (1991) Role of the cytoskeleton in glial-guided neuronal migration. J Cell Biol 115:102a.

Roberts JS, O'Rourke NA, McConnell SK (1993) Cell migration in cultured cerebral cortical slices. Dev Biol 155:396-408.

Ruegg MA, Tsim KWK, Horton SE, Kroger S, Escher G, Genesch EM, McMahan UJ (1992) The agrin gene codes for a family of basal lamina proteins that differ in function and distribution. Neuron 8:691699.

Saga Y, Yagi T, Ikawa Y, Sakakura T, Aizawa S (1992) Mice develop normally without tenascin. Genes Dev 6:1821-1831.

Schliwa M (1982) Action of cytochalasin D on cytoskeletal networks. J Cell Biol 92:79-91.

Schmerhel SF, Rakis P (1979) A Golgi study of radial glial cells in developing monkey telencephalon: morphogenesis and transformation into astrocytes. Anat Embryol (Berl) 156:115-152.

Schults CW, Hashimoto R, Brady RM, Gage FH (1990) Dopaminergic cells align along radial glia in the developing mesencephalon of the rat. Neuroscience 38:427-436.

Sheppard AM, Hamilton SK, Pearlman AL (1991) Changes in the distribution of extracellular matrix components accompany early morphogenetic events of mammalian cortical development. J Neurosci 11:3928-3942.

Shimamura K, Takeichi M (1992) Local and transient expression of E-cadherin involved in mouse embryonic brain morphogenesis. Development 116:1011-1019.

Sidman RL, Rakic P (1973) Neuronal migration, with special reference to developing human brain: a review. Brain Res 62:1-35.

Stevenson BR, Anderson JM, Bullivant S (1988) The epithelial tight junction: structure, function and preliminary biochemical characterization. Mol Cell Biochem 83:129-145.

Takeichi M (1991) Cadherin cell adhesion receptors as a morphogenetic regulator. Science 251:1451-1455.

Tawil NJ, Carbonetto S (1991) Immunocytochemical studies of integrins in type-2 astrocytes and oligodendrocytes. J Cell Biol 115 : 287a.

lawil NJ, Houde M, Blacher $\mathbf{K}$, Esch F, Reichardt LF, Turner DC, Carbonetto $S$ (1990) $\alpha 1 \beta 1$ integrin heterodimer functions as a dual laminin/collagen receptor in neural cells. Biochemistry 29:6540-6544.

Tawil N, Wilson P, Carbonetto S (1993) Integrins in point contacts mediate cell spreading: factors that regulate integrin accumulation in point contacts vs. focal contacts. J Cell Biol 120:261-271.

Towbin H, Staehlin T, Gordon J (1979) Electrophoretic transfer of proteins from polyacrylamide gels to nitrocellulose sheets: procedures and some applications. Proc Natl $\Lambda$ cad Sci USA 76:4350-4354.

Vogel H, Butcher EC, Picker LJ (1992) H-CAM expression in the human nervous system: evidence for a role in diverse glial interaclions. J Neurocylol 21:363-373.

Wacker IU, Rickard JE, De May JR, Kreis TE (1992) Accumulation of a microtubule-binding protein, pp 170 , at desmosomal plaques. $\mathrm{J}$ Cell Biol 117:813-824. 